\title{
Chemical and physical controls on the transformation of amorphous calcium carbonate into crystalline $\mathrm{CaCO}_{3}$ polymorphs
}

\author{
C.R. Blue ${ }^{1,2}$, A. Giuffre ${ }^{1,3}$, S. Mergelsberg ${ }^{1}$, N. Han ${ }^{1}$, J.J. De Yoreo ${ }^{4,5}$ and P.M. Dove ${ }^{1 *}$ \\ ${ }^{1}$ Department of Geosciences, Virginia Tech, Blacksburg, Virginia 24061, USA \\ ${ }^{2}$ Current Affiliation: eScience Labs Inc., Sheridan, CO 80110 USA \\ ${ }^{3}$ Current Affiliation: Departments of Physics and Chemistry, University of Wisconsin, Madison, \\ WI 53706 USA \\ $1 \quad{ }^{4}$ Physical Sciences Division, Pacific Northwest National Laboratory, Richland, WA 99352 USA \\ ${ }^{5}$ Department of Materials Science and Engineering, U. Washington, Seattle WA 98195 USA

\section{*Corresponding Author}

\begin{abstract}
Calcite and other crystalline polymorphs of $\mathrm{CaCO}_{3}$ can form by pathways involving amorphous calcium carbonate (ACC). Previous studies of ACC provide important insights, but apparent inconsistencies in the literature indicate the relationships between ACC composition, local conditions, and the subsequent crystalline polymorphs are not yet established. This experimental study quantifies the control of solution composition on the transformation of ACC into crystalline polymorphs in the presence of magnesium. Using a mixed flow reactor to control solution chemistry, $\mathrm{ACC}$ was synthesized with variable $\mathrm{Mg}$ contents by tuning input $\mathrm{pH}, \mathrm{Mg} / \mathrm{Ca}$, and total carbonate concentration. ACC products were allowed to transform within the output suspension under stirred or quiescent conditions while characterizing the evolving solutions and solids. As the ACC transforms into a crystalline phase, the solutions record a polymorph-specific evolution of $\mathrm{pH}$ and $\mathrm{Mg} / \mathrm{Ca}$.

The data provide a quantitative framework for predicting the initial polymorph that forms from ACC based upon the solution $a \mathrm{Mg}^{2+} / a \mathrm{Ca}^{2+}$ and $a \mathrm{CO}_{3}{ }^{2-} / a \mathrm{Ca}^{2+}$ and stirring versus quiescent conditions. This model reconciles apparent discrepancies among previous studies that report on the nature of the polymorphs produced from ACC and supports the previous claim that monohydrocalcite may be an important, but overlooked, transient phase on the way to forming some aragonite and calcite deposits. By this construct, organic additives and extreme $\mathrm{pH}$ are not required to tune the composition and nature of the polymorph that forms.

Our measurements show that the Mg content of ACC is recorded in the resulting calcite with $\mathrm{a} \approx 1: 1$ dependence. By correlating the composition of these calcite products with the $\mathrm{Mg}_{\text {tot }} / \mathrm{Ca}_{\text {tot }}$ of the initial solutions, we find $\mathrm{a} \approx 3: 1$ dependence that is approximately linear and general to whether the calcite is formed via an ACC pathway or by the classical step-propagation process. Comparisons to calcite grown in synthetic seawater show a $\approx 1: 1$ dependence. The relationships suggest that the local $\mathrm{Mg}^{2+} / \mathrm{Ca}^{2+}$ at the time of precipitation determines the calcite composition, independent of whether growth occurs via an amorphous intermediate or classical pathway for a range of supersaturations and $\mathrm{pH}$ conditions.

The findings reiterate the need to revisit the traditional picture of chemical and physical controls on $\mathrm{CaCO}_{3}$ polymorph selection. Mineralization by pathways involving ACC can lead to the formation of crystalline phases whose polymorphs and compositions are out of equilibrium with the local growth media. As such, classical thermodynamic equilibria may not provide a reliable predictor of observed compositions.
\end{abstract}




\section{INTRODUCTION}

Amorphous calcium carbonate (ACC) and other metastable $\mathrm{CaCO}_{3}$ phases are increasingly recognized as prevalent during calcification. Insights from these studies are motivating an extensive effort to revisit long-standing assumptions regarding $\mathrm{CaCO}_{3}$ mineralization and the factors that allow nonclassical, multistep pathways to mineralization (De Yoreo et al., 2015). Of particular interest are the relationships between the chemical composition of the local environment and the crystalline polymorphs that form. For example, the formation of calcified skeletons can involve the accumulation of ACC within the organic matrix followed by its transformation to anhydrous crystalline polymorphs (calcite, aragonite, and vaterite) or the hydrated polymorph, monohydrocalcite. Examples include sea urchin spicules (Beniash et al., 1997; Politi et al., 2008), sponge spicules (Aizenberg et al., 1996), mollusk shells (Nudelman et al., 2007; Weiss et al., 2002), pillbug cuticles (Tao et al., 2009) and crayfish gastroliths (Akiva-Tal et al., 2011).

ACC has received relatively little attention in the context of carbonate mineral formation in geological environments. Field observations, however, suggest that ACC may precipitate when conditions promote high local supersaturations for short periods of time. For example, some marine porewaters undergo pulses of increased alkalinity levels—due to either intrinsic (e.g., photosynthesis, respiration) or extrinsic (e.g., degassing, alkaline water input) factors (Dupraz et al., 2009) — on short time scales to produce ACC. More extreme environments such as saline lakes, sabkhas, and closed basin lakes can also achieve sufficiently high alkalinities to form ACC (Ingerson, 1962; Ross, 1991; Señorale-Pose et al., 2008; Sánchez-Roman et al., 2011; Katz and Nishri, 2013). ACC has also been identified in microbial mats (Dupraz et al., 2009) and hot spring deposits (Jones and Peng, 2012). The resulting crystalline polymorphs exhibit 
25 diverse morphologies, and a complex spread of elemental and isotopic signatures that are

26 extensively documented (Thompson and Ferris, 1990; Solotchina, et al., 2009; Katz and Nishri,

27 2013; Nielsen and DePaolo, 2013). Indeed, mineralization by ACC and other nonclassical

28 pathways may be the missing link to interpreting unusual carbonate compositions and textures

29 that are found in modern and ancient carbonates but not predicted by traditional crystal growth

30 models (Wang et al., 2012; Han et al., 2013; De Yoreo et al., 2015).

31 Given the importance of $\mathrm{Mg}$ as an indicator of paleoenvironmental conditions raises the

32 question of whether the mineralization process, in itself, influences calcite composition. The

33 many investigations that use $\mathrm{Mg}$ content of calcite to infer conditions of formation (e.g. Nürnberg

34 et al. 1996; Rosenthal et al., 1997; Lea, 1999; Russell et al., 2004) implicitly assume that 1)

35 growth occurs by the classical step-growth process of ion-by-ion attachment or 2) composition is

36 independent of the growth process, including mineralization by an amorphous pathway.

37 Recent studies of the crystalline transformation of ACC provide important insights, but a

38 quantitative picture of chemical controls on the polymorphs that form and their compositions are

39 not yet established. For example, Table 1 shows that ACC can transform to different crystalline

40 polymorphs, often as mixtures, and with highly variable Mg content. Discrepancies between the

41 results of these studies are due, in part, to the experimental methods, which could not control the

42 evolution of the solution chemistry during ACC precipitation. The most common experimental

43 approach uses variations on the batch-reactor method. This method involves stirring the

44 solutions during the transformation (Rodriguez-Blanco et al., 2012; Nishiyama et al., 2013) or

45 allowing the transformation to proceed without stirring (Loste et al., 2003; Han et al., 2013).

46 Most experiments mixed solutions of $\mathrm{CaCl}_{2}$ with $\mathrm{NaHCO}_{3}$ or began at higher $\mathrm{pH}$ values using 
$47 \mathrm{Na}_{2} \mathrm{CO}_{3}$ (Radha, et al., 2012). Other methods achieved rapid (and unknown) supersaturations by

48 sublimating a nearby $\left(\mathrm{NH}_{4}\right)_{2} \mathrm{CO}_{3}$ salt into $\mathrm{CaCl}_{2}$ solutions (Raz et al., 2000; Wang et al., 2012). ** TABLE $1 * *$

50 Although the observations reported in Table 1 are variable, they suggest that the

51 interplay of chemical and physical factors determine the initial polymorph that forms during

52 mineralization via an amorphous pathway. To test this idea, we designed a series of experiments

53 to quantify the control of local chemical composition on polymorphs and compositions (calcite)

54 that transform from ACC. The first part of the study used the mixed-flow reactor (MFR) method

55 to synthesize a suite of ACC materials under controlled chemical conditions (Blue et al., 2013;

56 Blue and Dove, 2015). By this approach, the Mg content of ACC is regulated by tuning the

57 initial solution $\mathrm{Mg} / \mathrm{Ca}$, total inorganic carbon concentration, and $\mathrm{pH}$. In the second part of the

58 study, the characterized ACC was allowed to transform into crystalline products under physically

59 mixed (stirred) or quiescent (unstirred) conditions.

60 The findings identify chemical and physical conditions that reproducibly direct the ACC

61 to transform into specific $\mathrm{CaCO}_{3}$ polymorphs and reiterate the importance of monohydrocalcite

62 as another potentially important metastable end-product phase (Rodriguez-Blanco et al., 2014).

63 This framework also shows the conditions that regulate the Mg content of calcite from low to

64 very high $\mathrm{Mg}$ values and do not require extreme solution $\mathrm{pH}$ or the presence/addition of organic

65 molecules. The resulting construct provides a chemical and physical basis for better

66 understanding $\mathrm{CaCO}_{3}$ polymorph selection, and calcite composition, while also reconciling

67 apparent discrepancies in the literature. 


\section{METHODOLOGY}

\subsection{ACC Synthesis}

ACC was synthesized at $25^{\circ} \mathrm{C}\left( \pm 1^{\circ} \mathrm{C}\right)$ using a mixed flow reactor (MFR) method adapted from Blue et al. (2013) (Figure 1). Advantages of the MFR over previous synthesis methods include: 1) synthesis at constant, quantified supersaturation under controlled chemical conditions, 2) continuous formation of the amorphous phase at steady-state conditions, and 3) production of large amounts of ACC with reproducible compositions for characterization by complementary methods.

The experimental design used a syringe pump to input two $100 \mathrm{~mL}$ solutions that contained variable concentrations of the salts 1) $\mathrm{MgCl}_{2} \bullet 6 \mathrm{H}_{2} \mathrm{O}$ and $\mathrm{CaCl}_{2} \cdot 2 \mathrm{H}_{2} \mathrm{O}$ and 2) $\mathrm{NaHCO}_{3}$. All experiments contained magnesium so that the resulting ACC would be stable for short periods prior to the transformation to crystalline products. Small amounts of $\mathrm{NaOH}$ were added to the $\mathrm{NaHCO}_{3}$ solution to adjust the initial $\mathrm{pH}$ to the desired value. Although the study was not designed to study $\mathrm{pH}$ specifically, the experiments were designed to span a portion of $\mathrm{pH}$ space with initial $\mathrm{pH}$ values ranging from 9.22-10.10 and the steady state values of 8.2-9.5. Input solution compositions are summarized in Appendix Table A1. The experimental design also used a range of saturation states to produce the ACC by varying carbonate concentration and $\mathrm{pH}$. Saturation states are reported with respect to pure calcite:

where $\Omega_{\text {calcite }}$ is the saturation state with respect to pure calcite, $a_{i}$ is the activity of species $i$, and the solubility product of calcite is given by $K_{s p \text {,calcite }}=10^{-8.48}$ at $25^{\circ} \mathrm{C}$ (Plummer and Busenberg, 1982). The experiments began with $\Omega_{\text {calcite }}$ in the range $27-82$ such that all solutions precipitated ACC. Our ability to produce ACC at relatively low calcite supersaturation is consistent with previous studies (Hamm et al., 2014; Kellermeier et al., 2014) suggesting the published ACC 
94 solubility of $K_{s p, A C C}=10^{-6.4}$ is too high (Brečević and Nielsen, 1989). Ion activities were

95 calculated using Geochemist's Workbench for each solution condition in order to quantify

96 saturation state.

97 To prepare ACC, the syringe pump continuously injected the two solutions $-\mathrm{NaHCO}_{3}$

98 and the $\mathrm{MgCl}_{2}$ and $\mathrm{CaCl}_{2}$ mixture - into the reactor, where they were stirred at $\approx 800 \mathrm{rpm}$. As the

99 contents of the MFR became supersaturated with respect to the amorphous phase, ACC

100 precipitated continuously (see Blue and Dove, 2015). All experiments prepared ACC using a 1-

101 minute hydraulic residence time $(\tau)$ :

102

$$
\tau=.
$$

103 For each experiment, the reactor operated for a minimum of three residence times to allow input 104 solutions and ACC products within the reactor to reach steady-state conditions (Jensen, 2001).

105 The time elapsed to steady state and the sample collection varied with solution chemistry. The 106 output suspension from the top of the reactor unit was sampled by vacuum filtration. The ACC

107 was collected on a SterliTech ${ }^{\circledR}$ polyethersulfone (PES) filter with a pore size of $0.03 \mu \mathrm{m}$ and the

108 effluent solution was retained in a vacuum flask. The steady state $\mathrm{pH}$ of the effluent solution

109 was measured within one minute of the termination of the experiment in order to minimize re-

110 equilibration from exposure to the atmosphere (Appendix Table A1). The produced ACC was

111 rinsed with ethanol and dried in a class II biological safety cabinet for 20 minutes, then dried for

112 an additional 10 minutes in a vacuum desiccator. Samples were subsequently weighed and

113 stored in a $4^{\circ} \mathrm{C}$ refrigerator overnight prior to analysis.

\section{$114 \quad 2.2$ ACC Transformation to Crystalline Products}

115 To conduct the transformation experiments, additional slurry was collected from the 116 MFR during the steady-state conditions of ACC production. Using a $100 \mathrm{~mL}$ glass vessel, the 117 suspension was stirred at $250 \mathrm{rpm}$, with a 1-minute rest interval each hour before reversing the 
118 rotation direction of the stir bar. All vessels were maintained at $25^{\circ} \mathrm{C}$ in a temperature monitored

119 room or incubator throughout the transformation process. Given the dependence of

120 transformation time on solutions composition (e.g. discussion in Section 3.2), the sampling

121 intervals varied with solution composition from 30 minutes to 12 hours, where low $\mathrm{Mg} / \mathrm{Ca}$

122 solutions were sampled the most frequently. Sampling continued until XRD and SEM analyses

123 showed the initial transformation was complete.

124 At each sampling interval (Appendix Table A1), $6 \mathrm{ml}$ of slurry was extracted from the

125 vessel during stirring for their respective analysis. The $\mathrm{pH}$ of the slurry was measured using

126 electrodes that were calibrated approximately every 2 hours using $\mathrm{pH} 7.0$ and 10.1 buffer

127 solutions at $25^{\circ} \mathrm{C}$. The solids were captured by vacuum filtration on a $0.03 \mu \mathrm{m}$ Nylon filter,

128 rinsed from the filter with ethanol into a petri dish, and saved for analysis. The filtered solution

129 was analyzed separately. The same transformation protocol was used for unstirred experiments,

130 except that they were not stirred after collection from the MFR. Stirred and unstirred

131 experiments were not run concurrently, and a new batch of ACC was prepared for each

132 transformation experiment (listed in Appendix Table A1).

133 Throughout the transformation process, $[\mathrm{Mg}]_{\text {tot }}$ and $[\mathrm{Ca}]_{\text {tot }}$ were also measured. Total

134 inorganic carbon concentration of the solution at a given time point was calculated by assuming

135 that all $\mathrm{Ca}$ and $\mathrm{Mg}$ removed from solution was precipitated according to the following

136 stoichiometry:

$137(1-x) \mathrm{Ca}^{2+}+x \mathrm{Mg}^{2+}+\left(\mathrm{CO}_{3}{ }^{2-}\right)+\mathrm{nH}_{2} \mathrm{O}=\mathrm{Ca}_{1-x} \mathrm{Mg}_{x}\left(\mathrm{CO}_{3}\right) \cdot \mathrm{nH}_{2} \mathrm{O}(\mathrm{ACC})$

138 Thus, the moles of $(\mathrm{Ca}+\mathrm{Mg})$ removed from solution must equal the moles of carbonate

139 removed from solution. Ion activities were calculated from the solution measurements using

140 Geochemist's Workbench (Appendix Table A1). 


\subsection{Sample Characterization}

\subsubsection{SEM}

All dried precipitates were placed on ultra smooth carbon tape and sputter-coated with $\approx 10 \mathrm{~nm}$ of gold-palladium. Analyses were performed on an FEI Quanta 600 FEG ESEM. Micrographs of the ACC and crystalline products were acquired using secondary electron (SE) scattering. All samples were examined for their morphology and particle size. SEM images of morphology and XRD analyses documented the formation of three anhydrous polymorphs (calcite, aragonite, and vaterite) and one hydrated polymorph of $\mathrm{CaCO}_{3}$ (monohydrocalcite: $\mathrm{CaCO}_{3} \bullet 1 \mathrm{H}_{2} \mathrm{O}$ ). Representative images are shown in Figure 2.

$* * *$ FIG. $2 * * *$

\subsubsection{XRD}

X-ray diffraction was used to confirm the mineralogy of each sample. The dried samples were prepared by pipetting $0.30 \mathrm{~mL}$ of an ethanol smear containing the filtered precipitate onto a zero background holder. Samples were then placed in a biological safety cabinet to allow the ethanol to completely evaporate at $25^{\circ} \mathrm{C}$ before analysis. All diffractograms were obtained using a Rigaku MiniFlex II, and data collected over $10^{\circ}-60^{\circ} 2 \theta$ at a step width of $0.05^{\circ}$ and a $5 \mathrm{~s}$ count time $(\lambda=1.5405 \AA)$. Standard spectra were collected from calcite (var. Iceland Spar) and aragonite (Ward's Science, USA) prior to sample analyses. Representative XRD patterns for each phase identified in this study are shown (Fig. 3)

$* * *$ FIG. $3 * * *$

\subsubsection{Inductively Coupled Plasma - Atomic Emission Spectrometry (ICP-AES)}

The composition of all solid products and their corresponding solutions were characterized separately by ICP-AES. The ACC samples collected from the MFR remained on the PES filters and were rinsed in ethanol, dried, and then immersed in $0.5 \mathrm{~N}$ nitric acid to 
165 dissolve the ACC. The products collected from the transformation experiments in the batch

166 reactor were washed from the filter with ethanol into a petri dish, dried in air in a Class II

167 Biological Safety Cabinet for 20 minutes, and dissolved using $0.5 \mathrm{~N}$ nitric acid. The resultant

168 filtered solutions were also mixed with $0.5 \mathrm{~N}$ nitric acid and analyzed. Analyses were performed

169 using a Spectro ARCOS SOP. An yttrium internal standard was added to each sample in an

170 internal standard mixing chamber (Glass Expansion, Inc., USA). Each sample then passed

171 through a cross-flow nebulizer into a modified Scott-style spray chamber. The sample uptake

172 rate was $2 \mathrm{~mL} / \mathrm{min}$, with each sample analysis using $5 \mathrm{~mL}$ of solution. Calibration solutions for

$173 \mathrm{Ca}$ and $\mathrm{Mg}$ were prepared from commercially available standards (Environmental Express, Inc.)

174 by dilution in a matrix-matched solution of $0.067 \mathrm{~N} \mathrm{HNO}_{3}$. The second source check standards

175 were obtained from Spex, Inc.

$176 \quad$ 2.3.4 Thermogravimetric Analysis

177 Thermogravimetric analyses of the ACC prepared by the same flow-through synthesis

178 methods showed that all amorphous calcium-magnesium carbonate (ACMC) products contain

179 slightly more than one water molecule (1.42-1.63) per carbonate ion (Blue and Dove, 2015).

180 This higher water contents was consistent with a previous report of ACMC formed at very high

$181 \mathrm{pH}$ (Radha et al., 2012). The water content and structure of the Mg-free ACC (control) is

182 consistent with TGA and NMR measurements (Schmidt et al., 2014). The analysis suggests

183 water associated with larger proportions of the charge-dense Mg compared to Ca (e.g. Di

184 Tommaso and de Leeuw, 2010; Rodriquez-Blanco et al., 2011; Cobourne et al., 2014). The

185 complexity of the spectra at higher temperatures (e.g. Blue and Dove, 2015) suggests that the

186 greater Mg content is correlated with differences in the hydroxyl content and structure. These

187 data suggest a relationship between the $\mathrm{Mg}$ and water contents of $\mathrm{ACMC}$, but Blue and Dove 
188 (2015) did not measure a dependence for the conditions of that study. Clearly, a detailed

189 structural investigation of ACMC is needed.

190 3. RESULTS

191 3.1 Characterization of ACC and Crystalline Products

192 Characterization of the initial ACC precipitates by scanning electron microscopy (SEM)

193 showed a characteristic spherical morphology with a particle size distribution of $\approx 0.1$ to $2.0 \mu \mathrm{m}$

194 (Fig. 2A). The polymorphs that transform from ACC exhibit a polycrystalline texture with

195 distinct morphologies. Calcite occurs as spherulites with surfaces that are increasingly rounded

196 as the Mg content increases and surface facets become smaller (i.e. Fig. 2B,C). Aragonite

197 exhibits clusters of needles (Fig. 2D), whereas monohydrocalcite generally assumes the twisted,

198 branching structure indicative of low Mg content (Rodriguez et al., 2014) (Fig. 2E), and vaterite 199 grows as spherical rosettes (Fig. 2F).

200 The initial ACC and the polymorphs associated with these morphologies were confirmed 201 by powder x-ray diffraction. All ACC products were confirmed as amorphous, without Bragg 202 peaks on the XRD pattern and only a broad peak displayed from $25^{\circ}-35^{\circ} 2 \theta$ (Fig. 3A). Spectra 203 for low-Mg calcite (Fig. 3B) nearly align with the pure calcite standard (Iceland Spar, Ward's 204 Science, USA), whereas peaks become broader and shift to higher $2 \theta$ with increasing Mg content 205 (Fig. 3C). Peak broadening may indicate the presence of small Mg-enhanced crystal domains 206 (Lenders et al., 2011). Mg content is also correlated with a decrease in d-spacing for all 207 reflections compared to the pure calcite standard (Fig. 3C). For example, the $2 \theta$ of the (104) 208 reflection increases from $29.583^{\circ}$ (pure calcite) to $29.727^{\circ}$ for calcite with 20 mole $\% \mathrm{Mg}$, which 209 corresponds to a reduction in d-spacing from $3.017 \AA$ to $3.003 \AA$. Peak broadening and smaller 210 d-spacing result from $\mathrm{Mg}$ incorporation into the crystallites (Bischoff et al., 1983; Mackenzie et 
211 al., 1983), which indicate that $\mathrm{Mg}^{2+}$ ions are located within the crystal structure rather than

212 adsorbed on surfaces as free ions (Vegard, 1921; Denton and Ashcroft, 1991).

213 All aragonite diffraction patterns (Fig. 3D) match the published standard (Ward's

214 Science, USA). Patterns for monohydrocalcite (Fig. 3E) and vaterite (Fig. 3F) are in good

215 agreement with those from other synthesis studies (e.g. Sand et al., 2011; Hu et al., 2012; Kimura

216 and Koga, 2011; Rodriguez-Blanco et al., 2014). Additional XRD data are provided and

217 discussed later in Appendix Figures A1 and A2.

$218 \quad 3.2$ Initial Crystalline Polymorphs Correlate with Solution Composition

219 The transformation of ACC produces crystalline polymorphs that indicate a systematic

220 relationship to solution composition. Recall that the ACC-aqueous slurries output from the MFR

221 at steady-state conditions (e.g. Section 2.2) were allowed to transform under physically stirred or

222 quiescent (unstirred) conditions. For the 34 experiments that transformed under stirred

223 conditions, Figure 4A shows that the initial calcite or monohydrocalcite occurs in reproducible

224 composition fields when plotted as a function of the $a \mathrm{Mg}^{2+} / a \mathrm{Ca}^{2+}$ and $a \mathrm{CO}_{3}{ }^{2-} / a \mathrm{Ca}^{2+}$ of the

225 solutions. This study did not specifically investigate the effect of $\mathrm{pH}$ but low values of $a \mathrm{CO}_{3}{ }^{2-}$

$226 / a \mathrm{Ca}^{2+}$ are roughly correlated with the lower steady-state $\mathrm{pH}$ that varied from $8.2-9.5$ (see

227 Methods).

228

*** FIG. $4 \mathrm{AB} * * *$

229

As expected, ACC transforms to calcite in solutions with a low $a \mathrm{Mg}^{2+} / a \mathrm{Ca}^{2+}$ (zero to $\approx 4$ )

230 and low $a \mathrm{CO}_{3}{ }^{2-} / a \mathrm{Ca}^{2+}$ (below dashed line in Fig. 4A). For solutions with intermediate

$231 a \mathrm{Mg}^{2+} / a \mathrm{Ca}^{2+}(4-8)$ and low $a \mathrm{CO}_{3}{ }^{2-} / a \mathrm{Ca}^{2+}(<0.5)$, ACC transforms to a mixture of aragonite and

232 calcite. The calcite that forms under the stirred transformation conditions contains $0-15 \mathrm{~mol} \%$

$233 \mathrm{MgCO}_{3}$ for conditions where the solution $\mathrm{Mg} / \mathrm{Ca}$ is less than $\approx 3.5-4$ (Fig. 5A). The 
234 transformation process is complete within 4 hours, according to XRD and SEM characterization

235 (Fig. 5A). Under these conditions, $15 \mathrm{~mol} \%$ is the uppermost $\mathrm{Mg}$ content measured and $\mathrm{Mg} / \mathrm{Ca}$

$236>6$ lead to the formation of monohydrocalcite from ACC (e.g. Fig. 4A).

239 the conditions investigated in this study. Our observations that aragonite typically forms only as

240 a late stage product is consistent with the notion that aragonite nucleation is limited by slow

241 kinetics in simple inorganic solutions (Loste et al., 2003; Wang et al., 2012). Pathways to

242 primary aragonite likely do exist, however, as seen in anecdotal reports that aragonite forms

243 directly from ACC in water-alcohol solutions (Sand et al., 2011) and during in-situ TEM

244 observations (Nielsen et al., 2014). These observations suggest the factors that regulate

245 aragonite formation are not yet fully established.

246 Similarly, one experiment produced vaterite at the lowest $a \mathrm{Mg}^{2+} / a \mathrm{Ca}^{2+}$ and lowest $a \mathrm{CO}_{3}{ }^{2-}$

$247 / a \mathrm{Ca}^{2+}-\mathrm{a}$ result that could not be replicated. Vaterite formation at very low $\mathrm{Mg}$ levels and high

248 precipitation rates is consistent with previous reports (e.g. Loste et al., 2003; Nishiyama et al.,

249 2013; Niedermayr et al., 2013) and observations that substrate composition also stabilizes the

250 formation of this relatively unstable polymorph (Smeets et al., 2015).

251 ACC transforms to monohydrocalcite under a broad range of conditions when the

252 solutions are stirred and the compositions have high $a \mathrm{Mg}^{2+} / a \mathrm{Ca}^{2+}$ and $a \mathrm{CO}_{3}{ }^{2-} / a \mathrm{Ca}^{2+}$ (Fig. 4A).

253 This result is consistent with reports of monohydrocalcite formation in Mg-rich solutions $(>0.01$

$254 \mathrm{M}$ ) and high solution $a \mathrm{CO}_{3}{ }^{2-} / a \mathrm{Ca}^{2+}(>1.0)$ (Loste et al., 2003; Kimura and Koga, 2011;

255 Nishiyama et al., 2013; Rodriguez-Blanco et al., 2014). The separate $a \mathrm{Mg}^{2+} / a \mathrm{Ca}^{2+}$ and $a \mathrm{CO}_{3}^{2-}$

$256 / a \mathrm{Ca}^{2+}$ solution fields that lead to calcite versus monohydrocalcite highlight the sensitivity of 
257 polymorph formation to chemical conditions-in this case through $a \mathrm{Mg}^{2+}$ and $a \mathrm{CO}_{3}{ }^{2-}$. The 258 solution $\mathrm{pH}$ is also a possible influential factor, primarily through controls on the $\mathrm{CO}_{3}{ }^{2-}: \mathrm{HCO}_{3}{ }^{-}$ 259 ratio.

260 Although this study focused on the initial polymorph that forms upon ACC

261 transformation, additional measurements and observations show that many of the initial products

262 eventually transform again into a tertiary solid phase. For example, most of the Mg-calcite is 263 consumed to produce aragonite, a transformation that is accompanied by small increases in $\mathrm{pH}$

264 (Appendix Table A1). Similarly, monohydrocalcite persists for only a few hours before 265 transforming to aragonite, minor nesquehonite $\left(\mathrm{MgCO}_{3} \bullet 3 \mathrm{H}_{2} \mathrm{O}\right)$, and possibly hydromagnesite $266\left(\mathrm{Mg}_{5}\left(\mathrm{CO}_{3}\right)_{4}(\mathrm{OH})_{2} \bullet 4 \mathrm{H}_{2} \mathrm{O}\right)($ Appendix Fig. A2). These observations concur with reports that 267 monohydrocalcite appears as a metastable intermediate between the precipitation of ACC and 268 late-stage formation of aragonite (Munemoto and Fukusi, 2008; Fukushi et al., 2011; Zhang et 269 al., 2012; Rodriguez-Blanco et al., 2014) and emphasize the point that monohydrocalcite 270 formation can be easily missed en route to final products.

271 The measurements also show the time required for ACC to transform to initial crystalline 272 products increases with the $\mathrm{Mg}_{\text {tot }} / \mathrm{Ca}_{\text {tot }}$ of the initial solution (Fig. 4B). For example, ACC 273 transforms to vaterite within 10 minutes at the lowest $\mathrm{Mg} / \mathrm{Ca}$ conditions (compare Fig. $4 \mathrm{~A}$ and 274 4B). At higher $\mathrm{Mg}_{\text {tot }} / \mathrm{Ca}_{\text {tot }}$, calcite typically forms within one hour; whereas aragonite or the 275 calcite-aragonite mixtures form in $<3-12$ hours. These measurements are consistent with reports 276 that Mg increases the lifetime of ACC (Loste et al., 2003; Wang et al., 2009, 2012; Rodriguez-

277 Blanco et al., 2012; Han et al., 2013), likely owing to the stronger hydration of Mg compared to 278 calcium (Burgess, 1988; Politi et al., 2010). At the highest $\mathrm{Mg} / \mathrm{Ca}$ levels that correspond to ACC 279 compositions of $>15 \mathrm{~mol} \% \mathrm{Mg}$, ACC transforms slowly to monohydrocalcite-sometimes 
280 requiring up to 50 hours for the conditions of these experiments (Fig. 4B). Measurements for

281 monohydrocalcite transformation show significant variability and may be caused by 1) high

282 metastability of monohydrocalcite in solutions with $a \mathrm{Mg}^{2+} / a \mathrm{Ca}^{2+}$ greater than 6.0 (Nishiyama et

283 al., 2013; Rodriquez-Blanco et al., 2014); 2) experimental and analytical error in accurately

284 estimating the longer transformation times; and 3) variable $\mathrm{CO}_{3}{ }^{2-}$ activity whereby higher levels

285 influence the rate of monohydrocalcite formation (compare Fig. 4A and Fig. 4B) (Kimura and

286 Koga, 2011; Nishiyama et al., 2013). Relationships in Fig. 4B further suggest the role of

287 solution composition in directing the initial polymorphs that form from ACC.

288 3.3 Quiescent Conditions Open Pathway to Very High Mg Calcite?

289 In contrast to stirred conditions, the ACC to crystalline transformation under unstirred

290 conditions expands the range of $\mathrm{Mg} / \mathrm{Ca}$ conditions that produce calcite. Although the

291 transformation is slow, requiring up to 40 hours (Fig. 5B), transformation experiments conducted

292 under quiescent conditions produce calcite when solution $\mathrm{Mg} / \mathrm{Ca}$ are as high as $10 . \mathrm{The} \mathrm{Mg}$

293 content of this calcite is extremely high (up to $26 \mathrm{~mol} \% \mathrm{MgCO}_{3}$ ) without evidence of

294 monohydrocalcite (Fig. 5B, Appendix Table A1). Characterization of these products by XRD

295 confirms that these are high $\mathrm{Mg}$ calcite and lack the (015) reflection that is characteristic of

296 dolomite. 


\section{DISCUSSION}

\subsection{Polymorph-Specific Evolution of Solution Chemistry during Transformation}

Our measurements show that solution compositions exhibit a polymorph-specific evolution of $\mathrm{pH}$ and solution $\mathrm{Mg}_{\mathrm{tot}} / \mathrm{Ca}_{\text {tot }}$. These patterns can be used to predict the polymorph into which ACC transforms and provide insight about the reaction stoichiometry.

\subsubsection{Calcite}

The onset of calcite formation is accompanied by an abrupt decrease in $\mathrm{pH}$ of approximately one unit, followed by an increase to relatively constant values (Fig. 6A). Calcites with a higher Mg content are associated with a slower transformation rate and thus slower a decrease in pH (Fig. 6A, exp. \#11). The ACC to calcite transformation is also accompanied by an approximately linear increase in $\mathrm{Mg}_{\text {tot }} / \mathrm{Ca}_{\text {tot }}($ Fig. 6B). This presumably occurs as the calcite consumes calcium relative to magnesium from solution and the additional drawdown of reactant

310 concentration with the precipitation of this lower solubility phase.

There are two explanations for the changes in solution composition (Fig. 4A and Fig.

313 6AB) that accompany the ACC to calcite transformation. First, the onset of calcite formation

314 would further decrease reactant concentration to approach the lower solubility of this phase

315 while releasing protons to solution. An additional contribution to a lower $\mathrm{pH}$ could come from

316 dissociation of bicarbonate in the ACC structure by the overall transformation reaction:

$$
\mathrm{Ca}_{1-x} \mathrm{Mg}_{x}\left(\mathrm{CO}_{3}\right)_{(1-0.5 y)}\left(\mathrm{HCO}_{3}\right)_{\mathrm{y}} \bullet \mathrm{nH}_{2} \mathrm{O}(\mathrm{ACC})=\mathrm{Ca}_{1-x} \mathrm{Mg}_{x}\left(\mathrm{CO}_{3}\right)(\mathrm{CAL})+\mathrm{yH}^{+}+\mathrm{nH}_{2} \mathrm{O} \text {. }
$$

318 This stoichiometry assumes: 1) Mg is conserved in the ACC to calcite transformation (Section

319 4.2) and 2) the ACC begins as a carbonate-bicarbonate solid solution. 
Although this second explanation is more speculative, three lines of evidence suggest

321 bicarbonate could be expected in ACC and may be significant in some settings. First, recall that

$322 \mathrm{ACC}$ in this study was synthesized at mild $\mathrm{pH}$ conditions that approximate $\mathrm{HCO}_{3}{ }^{-}$-dominated

323 environments of biogenic $\mathrm{CaCO}_{3}$ precipitation and most natural waters. Thus, the amorphous

324 polymorph may contain $\mathrm{HCO}_{3}{ }^{-}$ions. There is no structural or chemical basis to exclude the

325 presence of this species. Second, a recent $\mathrm{NMR}$ study detected minor $\mathrm{HCO}_{3}{ }^{-}$as intracrystalline

326 defects in calcites that transformed from ACC despite its synthesis in a very high $\mathrm{pH}$ solution

327 (Kababya et al., 2015). Third, a titration and NMR study of carbonate formation via a metastable

328 liquid carbonate phase indicate the presence of a Ca-bound bicarbonate species for experiments

329 conducted under similar $\mathrm{pH}$ conditions (Bewernitz et al., 2012). Thus, some component of the

330 original ACC formed in these mild conditions may contain bicarbonate suggesting further study

331 is warranted.

\subsubsection{Aragonite}

333 A similar evolution in $\mathrm{pH}$ was measured when $\mathrm{ACC}$ transformed to aragonite (Appendix

334 Table A1, exp. \#3) or vaterite (Appendix Table A1, exp. \#21,). For the one experiment that 335 transformed to aragonite, solution $\mathrm{Mg}_{\text {tot }} / \mathrm{Ca}_{\text {tot }}$ also increases approximately linearly but the ratio 336 becomes much larger (to 57), likely because Mg is preferentially excluded from the aragonite 337 structure.

\subsubsection{Monohydrocalcite}

The transformation of ACC to monohydrocalcite (MHC) occurs without a significant

340 change in the solution $\mathrm{pH}$ (Fig. 6C). This different type of pattern from the other polymorphs is

341 consistent with very small shifts reported by Rodriguez-Blanco et al. (2014). Nevertheless, the

342 onset of the transformation occurs with a sharp increase in solution $\mathrm{Mg}_{\text {tot }} / \mathrm{Ca}_{\text {tot }}$ to values 
343 approaching 80 to $>160$ (Fig. 6D). This behavior may explain the multi stage evolution of ACC

344 to a lower Mg MHC that is described by Rodriguez-Blanco et al. (2014). By monitoring the

345 formation of MHC from ACC using x-ray scattering methods, they found that ACC transforms

346 to high Mg MHC, to low Mg MHC and finally to aragonite/calcite. Data in our study supports

347 their multistage model with measurements showing that: 1) MHC formation is coincident with a

348 sharp increase in solution $\mathrm{Mg}_{\text {tot }} / \mathrm{Ca}_{\text {tot }}($ Fig. 6D); and 2) For experiments where we monitored

349 solution composition and polymorph after the transformation, all MHC and most calcite was

350 consumed and eventually transformed to aragonite (data not shown).

351 To better understand the ACC to MHC transformation, recall that MHC arises from ACC

352 that forms in solutions with high $a \mathrm{CO}_{3}{ }^{2-} / a \mathrm{Ca}^{2+}(>1.0)$ and $/$ or high $a \mathrm{Mg}^{2+} / a \mathrm{Ca}^{2+}(>6.0)$ (Fig. 4A).

353 Furthermore, the minor amounts of nesquehonite and hydromagnesite observed in a few

354 experiments (Appendix Fig. A2) leads us to speculate that some $\mathrm{MgCO}_{3}{ }^{\circ}$ may form during the

355 transformation. Accordingly, we can write the balanced reaction:

$356 \mathrm{Ca}_{1-x} \mathrm{Mg}_{x}\left(\mathrm{CO}_{3}\right) \bullet \mathrm{nH}_{2} \mathrm{O}(\mathrm{ACC})=\mathrm{Ca}_{1-\mathrm{x}-\mathrm{z}} \mathrm{Mg}_{x-z}\left(\mathrm{CO}_{3}\right) \bullet \mathrm{H}_{2} \mathrm{O}(\mathrm{MHC})+\mathrm{zMgCO}_{3}{ }^{\circ}(\mathrm{aq})+(\mathrm{n}-1) \mathrm{H}_{2} \mathrm{O}$

357 Comparisons of the trends in Figure 6 are consistent with the stoichiometries of

358 Reactions $(4,5)$ which show: 1) A sharp decrease in solution $\mathrm{pH}$ indicates $\mathrm{ACC}$ is transforming

359 to calcite whereas a marked increase in solution $\mathrm{Mg}_{\text {tot }} / \mathrm{Ca}_{\text {tot }}$ indicates the onset of MHC. The

360 data show that calcite formation is generally associated with lower alkalinity solutions, hence

361 their lower $\mathrm{pH}$ buffering capacity. 2) Under the conditions investigated in this study, however,

362 initial $\mathrm{pH}$ cannot be used to predict initial polymorph. Figures 6A,C show that ACC can

363 transform to calcite or MHC from similar $\mathrm{pH}$ solutions. 3) Monohydrocalcite formation and its

364 associated textures can be missed if $\mathrm{pH}$ alone is monitored. Temporal sampling of cation

365 concentration and solids is necessary to detect the appearance of this phase. 


\subsubsection{Insights for ACC structure and composition?}

The polymorph-specific evolution of solutions during the transformation raises the

368 question of whether 1) the initial ACC is formed with inherent structural and/or chemical

369 differences at the time of synthesis, or 2) the polymorphs are determined by conditions at the

370 time of ACC to crystal transformation. Figure $4 \mathrm{~A}$ suggests the latter process is predominant

371 with fields of polymorphs correlated with output solution composition. The isotope tracer study

372 of the ACC to calcite transformation is consistent with this interpretation (Giuffre et al., 2015).

373 Indeed, previous studies propose that ACC can display structural or chemical differences with a

374 'polyamorphism' that sets the stage for transformation to different crystalline polymorphs

375 (Gebauer et al., 2010; Cartwright et al., 2012). While speculative, our measurements of a

376 polymorph-dependent evolution of solution chemistry may support to this idea. The incipient

377 ACC may have distinct composition differences that include a carbonate-bicarbonate solid

378 solution. Also, Appendix Figure A3 shows the initial ACC synthesis conditions provide a

379 rough indication of the crystalline polymorphs into which it transforms (i.e., within the fields

380 similar to those in Figure 4A). Nevertheless, the comparison is inconclusive because the

381 compositions of the input solutions are correlated with the transformation solutions. It is also

382 possible that solution composition at the time of transformation biases the barriers to the

383 evolution of ACC to distinct crystalline products. The data do provide, however, a basis for

384 designing future structure and composition studies of ACC.

\section{4.2 Effects of an ACC Pathway on Calcite Composition}

386 The measurements in this study allow us to quantify the relationship between ACC

387 composition and the composition that is recorded in incipient calcite. By comparing the $\mathrm{Mg}$

388 content of ACC and the resulting calcite, we find a 1:1 relationship (Fig. 7). Acknowledging 
389 some scatter in the data with offsets of $\approx 1-3$ mole $\% \mathrm{MgCO}_{3}$ (see Appendix Table A2), the

390 approximately linear dependence appears general to calcites that form in stirred and unstirred

391 conditions. For calcites that form under mixed and quiescent conditions, respectively, the

392 relationship extends to $\approx 14 \%$ and almost $30 \mathrm{~mol} \% \mathrm{MgCO}_{3}$. Recall that the upper end of the

393 calcite range is limited for stirred conditions because MHC is produced (e.g. Fig. 4A and Fig.

394 5A).

395

*** FIG. $7 * * *$

Our finding of a simple 1:1 dependence suggests $\mathrm{Mg}$ signatures in calcite are determined 397 at the time of ACC precipitation. Thus, $\mathrm{Mg}$ partitioning into calcite to produce high $\mathrm{mol} \% \mathrm{Mg}$

398 must be controlled by local re-equilibration of solutions and solids at the time of transformation

399 for the conditions of these experiments. This interpretation is consistent with an isotope tracer

400 study of the ACC to calcite transformation (Giuffre et al., 2015) that concluded that the

401 transformation is dominated by a dissolution-reprecipitation process in the presence of bulk

402 solution. Hence, the Mg content of the ambient/parental solution is recorded in the subsequent

403 growth of calcite during the transformation. Additional investigations report a similar

404 dependence on the Mg content of ACC and calcite (Wang et al., 2012; Han et al., 2013), but they

405 show the 1:1 dependence breaks down at very high solution $\mathrm{Mg} / \mathrm{Ca}$ levels (up to 80 and 16 ,

406 respectively) such that the amount of $\mathrm{Mg}$ in calcite reaches a plateau at about 35-40 mol \%

$407 \quad \mathrm{MgCO}_{3}$.

408 Detailed structural analyses during the transformation will be necessary to decipher the

409 processes by which physical mixing influence the resulting polymorphs and their compositions.

410 We hypothesize that quiescent conditions create a diffusion-limited environment that allows

411 local solution $\mathrm{Mg} / \mathrm{Ca}$ to increase to extreme levels as the calcite begins to precipitate. Because 
$412 \mathrm{Mg}$ is a strong inhibitor to calcite growth (Lippman, 1973; Folk, 1974; Morse, 1983; Davis et al.,

413 2000; Stephenson et al., 2008), the transformation must proceed by reducing the free energy

414 (supersaturation) through nucleation, i.e. the ACC spherulites relax to produce a Mg-rich calcite

415 (Wang et al., 2012; De Yoreo et al., 2015). The comparable size of the high-Mg calcite

416 spherulites and the original ACC particles support this explanation (compare Fig. 2A, B, C).

\section{4.3 Dependence of Calcite Composition on ACC versus Classical Pathway}

418 The measurements in this study also present an opportunity to compare the $\mathrm{Mg}$ content of

419 calcites formed via transformation of ACC versus a classical growth process. Both processes are

420 active in biological and geological systems, but environmental proxy models that investigate

421 calcite composition make the implicit assumption that signatures are independent of

422 crystallization process. To explore this question, we compare the Mg content of calcites grown

423 by two pathways relative to their initial parental solution composition: 1) non-classical two-step

424 process via ACC (this study) and 2) direct growth from solution by classical step propagation in

425 simple $\mathrm{Mg}-\mathrm{Ca}-\mathrm{CO}_{3}$ solutions and synthetic seawater.

426 To compare the measurements in this study with previous investigations that report the

427 composition of calcite that grew by step propagation, we compiled data using three criteria: 1 )

428 provide direct evidence for growth by step propagation or make direct claim of classical crystal

429 growth; 2) report $\mathrm{Mg}$ content of the resulting calcite; and 3) provide sufficient information to

430 determine the parental solution $\mathrm{Mg} / \mathrm{Ca}$. To our knowledge, only five other studies meet all of

431 these criteria. The AFM studies of calcite step growth (Davis et al., 2000; Stephenson et al.,

432 2008) assume the input/output compositions of these high flow rate experiments are

433 approximately equal. Seeded growth measurements conducted in synthetic seawater were also

434 included in our comparisons using data compiled in Mucci and Morse (1990) from three 
435 previous studies (Mucci and Morse, 1983; Mucci et al., 1985; Mucci, 1987). Note that some of

436 the $25^{\circ} \mathrm{C}$ data points were interpolated from $5^{\circ} \mathrm{C}$ and $40^{\circ} \mathrm{C}$ data. All data are summarized in

437 Appendix Table A3.

438 The resulting trend in Figure 8 indicates the Mg content of calcite grown by an ACC or

439 classical step growth pathway is correlated with solution $\mathrm{Mg}_{\text {tot }} / \mathrm{Ca}_{\text {tot }}$ at the time of initial

440 precipitation. Data from this study reports the x-axis using the composition of the output

441 solution that was separated from the ACC-solution slurry. Fitting a linear function to the 34

442 measurements reporting calcite formation in simple solutions gives:

$$
\mathrm{mol} \% \mathrm{MgCO}_{3} \text { (calcite) }=(3.08 \pm 0.15)\left[\mathrm{Mg}_{\text {tot }} / \mathrm{Ca}_{\text {tot }}\right]
$$

443 where $\mathrm{R}^{2}=0.89$. The $\approx 3: 1$ relationship is general to calcite growth where bulk water is present,

444 and the correlation exists whether the solution is mixed or quiescent during growth by a step

445 propagation process or via an ACC intermediate.

446 For comparison, the $\mathrm{Mg}$ content of calcites grown in synthetic seawater using a seeded

447 growth method are also shown using data summarized in Mucci and Morse (1990) from three

448 previous studies. These measurements also produce a linear trend:

$$
\mathrm{mol} \% \mathrm{MgCO}_{3}(\text { calcite })=(1.16 \pm 0.05)\left[\mathrm{Mg}_{\text {tot }} / \mathrm{Ca}_{\text {tot }}\right]
$$

449 where $\mathrm{R}^{2}=0.92$. Thus, the relationship for synthetic seawater shows a lower slope with a $\approx 1: 1$

450 dependence. This study cannot deduce the physical basis for the different dependences in Eq (6)

451 and (7), the lower slope associated with synthetic seawater is consistent with laboratory

452 measurements showing that synthetic seawater suppresses the Mg content of calcite (Zhong and

453 Mucci, 1989) — a result that was explained by competition from sulfate ion. For further

454 discussion of this and other studies that investigated the effect of ionic strength on calcite

455 composition, see Stephenson et al. (2011) and Table 1 therein. 

calcite compositions produced by multiple pathways (to our knowledge). Nevertheless, we

459 recognize that the data set is limited and Eq (6) should be interpreted with caution. The number 460 of available data is relatively small, and span of values determined from the AFM studies are

461 limited to very low Mg concentrations because step propagation becomes immeasurably slower 462 at higher levels (Davis et al., 2000; Stephenson et al., 2008). Finally, the low supersaturation 463 conditions associated with step growth do not have significant overlap with the high 464 supersaturations associated with a transformation from ACC, as a consequence of the different 465 growth methods. In spite of these differences, 34 data points from multiple studies conducted 466 over a range of supersaturation values show a correlation that reiterates the primary control on $467 \mathrm{Mg}$ content of calcite is the $\mathrm{Mg}$ :Ca ratio of the initial mineralizing solution. More importantly, 468 in the presence of bulk solutions, the relationship suggests the process by which calcite forms is 469 secondary.

\section{CONCLUSIONS AND IMPLICATIONS}

475 chemical conditions and monitor the evolution of ACC to crystalline products within the bulk 476 solution. For the conditions of this study, the measurements show three variables are important 477 in determining the crystalline polymorph that forms - two chemical and one physical. First, the 478 data reiterate the importance of $\mathrm{Mg} / \mathrm{Ca}$ as a master variable in carbonate mineralization. High 479 ratios increase the lifetime of ACC and influence the type of crystalline polymorph that forms as 480 the initial and the long-term product. The data suggest that $\mathrm{CO}_{3}{ }^{2-} / \mathrm{Ca}^{2+}$ may be an important, 
481 second, master variable (Fig. 4AB). Indeed, previous laboratory and field studies report

482 anecdotal evidence that the $\mathrm{CO}_{3}{ }^{2-}$ concentration and $\mathrm{CO}_{3}{ }^{2-} / \mathrm{Ca}^{2+}$ are significant variables in

483 polymorph selection (Sandberg, 1983; Mackenzie and Pigott, 1981; Given and Wilkinson, 1985;

484 Wilkinson and Given, 1986; Rodriguez-Blanco et al., 2014).

485 As a third variable, physical mixing further influences the initial polymorph that forms

486 from ACC. Stirred solutions produce MHC as a metastable intermediate over a wide range of

487 conditions. In contrast, quiescent conditions slow the rate of ACC transformation and enlarge

488 the range of solution compositions $\left(a \mathrm{Mg}^{2+} / a \mathrm{Ca}^{2+}>12\right)$ that produce calcite. This combination of

489 composition and mixing opens a pathway to the formation of very high $\mathrm{Mg}$ calcites (up to 26

$\left.490 \mathrm{~mol} \% \mathrm{MgCO}_{3}\right)$. Neither organic molecules nor extreme $\mathrm{pH}$ is required.

491 This interplay of chemical and physical conditions provides a framework for reconciling

492 apparent inconsistencies (e.g. discussion of Table 1) between previous studies that investigated

493 ACC and the crystalline polymorphs it transformed into. Returning to Table 1, seven studies

494 report that stirred conditions produce calcites with relatively lower Mg contents. Although three

495 different experimental methods are used, they consistently show that ACC transforms to calcites

496 with $0-8 \mathrm{~mol} \% \mathrm{MgCO}_{3}$ with stirring. In contrast, eight studies that investigated the ACC

497 transformation in the absence of stirring produced very high-Mg calcite. Reports that some

498 products contain $30-40 \mathrm{~mol} \% \mathrm{Mg}$ are consistent with our finding (e.g. Table 1).

499 5.2 Monohydrocalcite: An Overlooked Polymorph?

500 Our observations that ACC transforms to monohydrocalcite as the initial phase for a

501 broad range of solution compositions suggests MHC may be an often overlooked polymorph.

502 This metastability of MHC is consistent with sparse occurrences in natural settings. As a

503 biomineral, MHC is limited to highly specific environments such as the calcareous corpuscles of 
504 tapeworms (Señorale-Pose et al., 2008), the guinea pig bladder stone (Catherine et al., 1977),

505 some bacterial cultures (Rivadeneyra et al., 2004), skeletal products in some mollusks

506 (Lowenstam, 1981), vertebrate otoliths (Carlström, 1963), and as a decay product of the Saguaro

507 cactus (Garvie, 2003). In geologic settings, MHC is associated with extreme environments that

508 contain significant magnesium and other ions that apparently inhibit the formation of calcite and

509 aragonite. Good examples are found in the sediments of saline alkaline lakes (Stoffers and

510 Fischbeck, 1974; Taylor, 1975; Swainson, 2008; Last et al., 2010; Nishiyama et al., 2013), saline

511 spring waters (Ito, 1993), the speleothems of limestone (Fischbeck and Müller, 1971) and

512 basaltic caves (Léveillé et al., 2000), as well as polar systems (Bird et al., 1991; Dahl and

513 Buchardt, 2006). In these environments, MHC is typically associated with calcite, aragonite,

514 dolomite $\left(\mathrm{Ca}, \mathrm{Mg}\left(\mathrm{CO}_{3}\right)_{2}\right)$, hydromagnesite, and nesquehonite $\left(\mathrm{MgCO}_{3} \bullet 3 \mathrm{H}_{2} \mathrm{O}\right)($ Fischbeck and

515 Müller, 1971; Nishiyama et al., 2013).

516 Despite limited occurrences of MHC in natural systems, there is potential for its

517 widespread formation as a metastable phase. The findings in this study lead us to concur with

518 the conclusion that some calcite and aragonite deposits may have secondary origins (Rodriguez-

519 Blanco et al., 2014). The role of MHC as an intermediate phase is demonstrated by the absence

520 of a pH shift during the ACC transformation (Fig. 6B) in contrast to the marked decrease in $\mathrm{pH}$

521 that signals the onset of calcite formation (compare Fig. 4A). In the lab, these findings call for

522 careful monitoring (solution $\mathrm{Mg} / \mathrm{Ca}$ levels) and repeated analysis of solids to obtain a more

523 accurate picture of transformation processes. In the field, long-standing assumptions regarding

524 calcification should consider multi-step pathways to mineral formation that may include MHC. 


\subsection{Consequences of an Amorphous Pathway for Calcite Composition}

The quantitative design of this study allows us to explore the consequences of an amorphous pathway on $\mathrm{Mg}$ signatures in calcite. First, we find a 1:1 relationship between the $\mathrm{Mg}$ content of $\mathrm{ACC}$ and the subsequent calcite that forms. The trend is general to calcites that transform under both stirred (limited range) and unstirred conditions over compositions of 0-26 $\mathrm{mol} \% \mathrm{MgCO}_{3}$. This finding is consistent with evidence that the ACC to crystal transformation process occurs by dissolution-reprecipitation when water is present (Giuffre, et al., 2015). The ACC pathway extends the amount of $\mathrm{Mg}$ that can be incorporated into the calcite products. For example, calcite that forms via a simple step growth process and cannot incorporate more than $4 \% \mathrm{MgCO}_{3}$ (Davis et al., 2000) while we show that calcite with up to $26 \% \mathrm{MgCO}_{3}$ becomes possible. Here, reprecipitation likely involves nucleation and aggregation of $\mathrm{Mg}$-rich calcite particles.

We further find $\mathrm{a} \approx 3: 1$ relationship between the solution ratio of $\mathrm{Mg}_{\text {tot }} / \mathrm{Ca}_{\text {tot }}$ and the mole $\% \mathrm{MgCO}_{3}$ of the resulting calcite. Although the number of measurements is limited, the data from experiments that were conducted in bulk solutions indicate the $\mathrm{Mg}$ content of the final calcite could be independent of formation by a classical versus ACC pathway.

The single composition trend that emerges for both pathways raises the question of whether most calcite compositions are far from equilibrium. The 1:1 dependence between the Mg content of initial ACC and the composition of the resulting calcite (Fig 7) shows the ACC transforms without excluding $\mathrm{Mg}$ to give a final product that is far from equilibrium in terms of Mg content. Yet, the compositions of the calcites originating from ACC fall along a similar trend to those produced by a classical step growth process (Fig. 8). The logical conclusion from 
550 the findings is that all of these laboratory-formed calcites, regardless of mineralization process,

551 are recording nonequilibrium compositions.

$552 \quad 5.4$ Traditional Picture of Carbonate Formation Needs to be Revisited.

553 Insights from our study suggest the traditional picture of controls on $\mathrm{CaCO}_{3}$ polymorph

554 selection needs to be revisited. Most early investigations assumed the sequential appearance of

555 crystalline polymorphs is governed by the Ostwald step rule (as noted later) and the role of

556 kinetics was debated. For example, the appearance of aragonite instead of calcite at sufficiently

557 high $\mathrm{Mg}^{2+}$ concentrations was attributed to the reversal of the order of the apparent solubility of

$558 \mathrm{Mg}$-calcite relative to aragonite, but the observation that aragonite is the only polymorph to

559 spontaneously form from supersaturated seawater could also argue for the role of kinetic factors

560 (see discussions in Carlson, 1983 and Morse, 1983). Yet, other studies recognized kinetics could

561 determine the initial polymorph to form and influence composition (Matthews, 1968; Given and

562 Wilkinson, 1985). For these relatively simple solution compositions, we show that, even at $\mathrm{Mg}^{2+}$

563 concentrations where aragonite will eventually dominate, the initial precipitate is calcite.

564 In that regard, the sequence of calcite-to-aragonite is analogous to initial ACC formation

565 followed by transformation to $\mathrm{MHC}$, calcite, or aragonite. It is an example of the heuristic

566 known as the Ostwald-Lussac rule of stages — also called the Ostwald step rule — wherein a

567 metastable phase, whose appearance would not be predicted based on thermodynamic stability,

568 appears initially for kinetic reasons and is replaced over time by progressively more

569 thermodynamically stable phases (De Yoreo et al., 2015). This behavior, though often called

570 non-classical, may be completely consistent with the expectations of classical nucleation theory.

571 Our previous analysis shows that creating a classical nucleation barrier small enough to permit

572 nucleation of the stable $\mathrm{CaCO}_{3}$ phase on a reasonable timescale, requires a supersaturation that is 
573 sufficiently high to render all other phases potential metastable intermediates (Hu et al., 2012).

574 Because the nucleation barrier scales with the cube of the interfacial energy and the latter scales

575 inversely with solubility (De Yoreo and Vekilov, 2003), as aragonite becomes less soluble than

576 calcite at greater $\mathrm{Mg}$ concentrations, the nucleation barrier is thus expected to exceed that of

577 calcite at sufficiently high supersaturation, leading to the observed order of appearance.

578 This reaffirms the point that some calcite and aragonite deposits may have formed under

579 conditions that allowed alternative pathways and thus could be of secondary origin (e.g.

580 Rodriguez-Blanco et al., 2014). For example, high-Mg calcite and monohydrocalcite transform

581 to aragonite over long periods, but early studies (Berner, 1975; Mucci and Morse, 1983; Bischoff

582 et al., 1987) may not have had the temporal resolution to identify intermediate phases and

583 recognize a sequential process. As seen in this study, early phases influence local solution

584 composition and the morphology/texture of the early stage products. Similarly, the ability of

585 organisms to precisely control local alkalinity, $\mathrm{pH}$, and thus supersaturation during calcification

586 could also enable precipitation of metastable phases (Dupraz et al., 2009; Gagnon et al., 2013).

587 Macromolecules impose an additional level of control.

588 Other aspects of the traditional picture may also be incomplete. To our knowledge,

589 physical mixing is not widely recognized as a control on polymorph selection in geologic

590 settings. Exceptions are seen in reports that chemical/physical mixing zones influence dolomite

591 formation and low- versus high-energy settings (Folk and Land, 1975; Hardie, 1987). Also,

592 Duguid et al. (2010) consider the influence of wave energy on ooid structure and composition.

593 As a mechanism-based picture of calcification begins to emerge, we may find alternate pathways

594 are the missing link to interpreting the unusual calcite compositions and textures that occur in

595 geological and biological systems but unexplained by traditional crystal growth models. 
598 ACKNOWLEDGEMENTS

599 This material is based upon work supported by the National Science Foundation NSF

600 OCE-1061763 (PMD) and the U.S. Department of Energy Office of Science, Office of Basic

601 Energy Sciences under Award Number BES-FG02-00ER15112 (PMD), and by the U.S.

602 Department of Energy, Office of Basic Energy Sciences at the Pacific Northwest National

603 Laboratory (PNNL). PNNL is operated by Battelle for the U.S. Department of Energy under

604 Contract DE-AC05-76RL01830. This work was also supported by the Office of Science, Office

605 of Basic Energy Sciences, Division of Chemical Sciences, Geosciences, and Biosciences of the

606 USDOE under Contract DE-AC02-05CH11231. The opinions, findings, conclusions or

607 recommendations expressed in this material are those of the authors and do not necessarily

608 reflect the views of the DOE or the NSF. We thank Al Mucci, Bruce Watson, and two

609 anonymous reviewers for insightful comments that improved the manuscript during review. 


\section{REFERENCES}

Aizenberg J., Addadi L., Weiner S. and Lambert G. (1996) Stabilization of amorphous calcium carbonate by specialized macromolecules in biological and synthetic precipitates. $A d v$. Mater. 8, 222-226.

Akiva-Tal A., Kababya S., Balazs Y. S., Glazer L., Berman A., Sagi A. and Schmidt A. (2011) In situ molecular NMR picture of bioavailable calcium stabilized as amorphous $\mathrm{CaCO}_{3}$ biomineral in crayfish gastroliths. Proc. Natl. Acad. Sci. U. S. A. 108, 14763-14768.

Beniash E., Aizenberg J., Addadi L. and Weiner S. (1997) Amorphous calcium carbonate transforms into calcite during sea urchin larval spicule growth. Proc. R. Soc. London B: Biol. Sci. 264, 461-465.

Berner R. A. (1975) The role of magnesium in the crystal growth of calcite and aragonite from sea water. Geochim. Cosmochim. Acta 39, 489-504.

Bewernitz M. A., Gebauer D., Long J., Cölfen H. and Gower L. B. (2012) A metastable liquid precursor phase of calcium carbonate and its interactions with polyaspartate. Faraday Discuss. 159, 291-312.

Bird M. I., Chivas A. R., Radnell C. J. and Burton H. R. (1991) Sedimentological and stableisotope evolution of lakes in the Vestfold Hills, Antarctica. Palaeogeo., Palaeoclim., Palaeoeco. 84, 109-130.

Bischoff W. D., Bishop F .C. and Mackenzie F. T. (1983) Biogenically produced magnesian calcite: Inhomogeneities in chemical and physical properties; comparison with synthetic phases. Am. Mineral. 68, 1183-1188.

Bischoff W. D., Mackenzie F. T. and Bishop F. C. (1987) Stabilities of synthetic magnesian calcites in aqueous solution: Comparison with biogenic materials. Geochim. Cosmochim. Acta 51, 1413-1423.

Blue C. R., Rimstidt J. D. and Dove P. M. (2013) Chapter twenty-three - A mixed flow reactor method to synthesize amorphous calcium carbonate under controlled chemical conditions. In Research Methods in Biomineralization Science. Methods in Enzymology, vol. 532 (ed. J. De Yoreo), Academic Press, UK, 557-568.

Blue C. R. and Dove P. M. (2015) Chemical controls on the magnesium content of amorphous calcium carbonate. Geochim. Cosmochim. Acta. 148, 23-33.

Brečević L. and Nielsen A. E. (1989) Solubility of amorphous calcium carbonate. J. Cryst. Growth 98, 504-510.

Burgess J. (1988) Ions in Solution. Halsted Press, New York.

Carlson W.D. (1983) The polymorphs of $\mathrm{CaCO} 3$ and the calcite-aragonite transformation. In Carbonates: Mineralogy and Chemistry. Reeder R. J. (ed.) Rev. Mineral. 11, 191-226.

Carlström D. (1963) A crystallographic study of vertebrate otoliths. Biol. Bulletin 125, 441-463.

Cartwright J. H. E., Checa A. G., Gale J. D., Gebauer D. and Sainz-Díaz C. I. (2012) Calcium carbonate polyamorphism and its role in biomineralization: How many amorphous calcium carbonates are there? Angew. Chem. Int. Ed. 51, 11960-11970.

Catherine H., Skinner W., Osbaldiston G. W. and Wilner A. N. (1977) Monohydrocalcite in a guinea pig bladder stone, a novel occurrence. Am. Mineral. 62, 273-277.

Cobourne G., Mountjoy G., Rodriguez-Blanco J. D., Benning L. G., Hannon A. C. and Plaisier J. R. (2014) Neutron and X-ray diffraction and empirical potential structure refinement modeling of magnesium stabilised amorphous calcium carbonate. J. Non Cryst. Solids. 401, 154-158. 
Dahl K. and Buchardt B. (2006) Monohydrocalcite in the arctic Ikka Fjord, SW Greenland: First reported marine occurrence. J. Sed. Res. 76, 460-471.

Davis K .J., Dove P. M. and De Yoreo J. J. (2000) The role of $\mathrm{Mg}^{2+}$ as an impurity in calcite growth. Science 290, 1134-1137.

Denton A. R. and Ashcroft N. W. (1991) Vegard's law. Phys. Rev. A 43, 3161-3164.

De Yoreo J. J. and Vekilov P.G. (2003) Principle of crystal nucleation and growth. In: Reviews in Mineralogy and Geochemistry: Biomineralization. Dove P.M., De Yoreo J.J., and Weiner S. (eds.) 54: 57-93.

De Yoreo J. J. Gilbert P. U.P. A., Sommerdijk N. A. J. M., Penn R. L., Whitelam S., Joester D., Zhang H. Z., Rimer J. D., Navrotsky A., Banfield J. F., Wallace A. F., Michel F. M., Meldrum F. C., Cölfen H. and Dove P. M. (2015) Crystallization by particle attachment in synthetic, biogenic, and geologic environments. Science 349, aaa6760-1-6760-9.

Di Tommaso D. and de Leeuw N. H. (2010) First principles simulations of the structural and dynamical properties of hydrated metal ions $\mathrm{Me}^{2+}$ and solvated metal carbonates $(\mathrm{Me}=\mathrm{Ca}$, $\mathrm{Mg}$, and Sr). Cryst. Growth Des. 10, 4292-4302.

Duguid S. M. A., Kyser T. K., James N. P., and Rankey E. C. (2010) Microbes and ooids. J. Sed. Res. 80, 236-251.

Dupraz C., Reid P. R., Braissant O., Decho A. W., Norman R. S. and Visscher P. T. (2009) Processes of carbonate precipitation in modern microbial mats. Earth-Sci. Rev. 96, 141-162.

Fischbeck R. and Müller G. (1971) Monohydrocalcite, hydromagnesite, nesquehonite, dolomite, aragonite, and calcite in speleothems of the Fränkische Schweiz, Western Germany. Contr. Mineral. and Petrol. 33, 87-92.

Folk R. L. (1974) The natural history of crystalline calcium carbonate: Effect of magnesium content and salinity. J. Sed. Res. 44, 40-53.

Folk R. L. and Land L. S. (1975) Mg/Ca ratio and salinity: Two controls over crystallization of dolomite. AAPG Bull. 59, 60-68.

Fukushi K., Munemoto T., Sakai M. and Yagi S. (2011) Monohydrocalcite: A promising remediation material for hazardous anions. Sci. Technol. Adv. Mater. 12, 1-12.

Gagnon A. C., Adkins J. F., Erez J., Eiler J. M. and Guan Y. (2013) Sr/Ca sensitivity to aragonite saturation state in cultured subsamples from a single colony of coral: Mechanism of biomineralization during ocean acidification. Geochim. Cosmochim. Acta 105, 240-254.

Garvie L. A. J. (2003) Decay-induced biomineralization of the saguaro cactus (Carnegiea gigantea). Am. Mineral. 88, 1879-1888.

Gebauer D, Gunawidjaja P. N., Ko J. Y. P., Bacsik Z., Aziz B., Liu L., Hu Y., Bergström L., Tai C. W., Sham T. K., Edén M., and Hedin N. (2010) Proto-calcite and proto-vaterite in amorphous calcium carbonates. Angew. Chem. 122, 9073-9075.

Given R. K. and Wilkinson B. H. (1985) Kinetic control of morphology, composition, and mineralogy of abiotic sedimentary carbonates. J. Sed. Petr. 55, 0109-0119.

Giuffre A. J., Gagnon A. C., De Yoreo J. J. and Dove P. M. (2015) Isotopic tracer evidence for the amorphous calcium carbonate to calcite transformation by dissolution-reprecipitation. Geochim. Cosmochim. Acta 165, 407-417.

Hamm L. M., Giuffre A. J., Han N., Tao J., Wang D., De Yoreo J. J. and Dove P. M. (2014) Reconciling disparate views of template-directed nucleation through measurement of calcite nucleation kinetics and binding energies. Proc. Natl. Acad. Sci. U. S. A. 111, 13041309. 
Han N., Blue C. R., De Yoreo J. J. and Dove P. M. (2013) The effect of carboxylates on the Mg content of calcites that transform from ACC. Proc. Earth Planet. Sci. 7, 223-227.

Hardie L. A. (1987) Dolomitization: A critical view of some current views: PERSPECTIVES. $J$. Sed. Res. 57, 166-183.

Hu Q., Zhang J., Teng H. and Becker U. (2012) Growth process and crystallographic properties of ammonia-induced vaterite. Am. Mineral. 97, 1437-1445.

Ingerson E. (1962) Problems of the geochemistry of sedimentary carbonate rocks. Geochim. Cosmochim. Acta 26, 815-847.

Ito T. (1993) The occurrence of monohydrocalcite from calcareous sinter of cold spring of Shiowakka, Asyoro, Hokkaido. J. Min. Petr. Econ. Geol 88, 485-491.

Jensen J .N. (2001) Approach to steady state in completely mixed flow reactors. J. Environ. Engineer. 127, 13-18.

Jones B. and Peng X. (2012) Amorphous calcium carbonate associated with biofilms in hot spring deposits. Sed. Geol. 269-270, 58-68.

Kababya S., Gal A., Kahil K., Weiner S., Addadi L. and Schmidt A. (2015) Phosphate-water interplay tunes amorphous calcium carbonate metastability: Spontaneous phase separation and crystallization vs stabilization viewed by solid state NMR. J. Am. Chem. Soc. 137, 990-998.

Katz A. and Nishri A. (2013) Calcium, magnesium and strontium cycling in stratified, hardwater lakes: Lake Kinneret (Sea of Galilee), Israel. Geochim. Cosmochim. Acta 105, 372-394.

Kellermeier M., Picker A., Kempter A., Cölfen H. and Gebauer D. (2014) A straightforward treatment of activity in aqueous $\mathrm{CaCO}_{3}$ solutions and the consequences for nucleation theory. Adv. Mater. 26, 752-757.

Kimura T. and Koga N. (2011) Monohydrocalcite in comparison with hydrated amorphous calcium carbonate: Precipitation condition and thermal behavior. Cryst. Growth and Des. 11, 3877-3884.

Last F. M., Last W. M. and Halden N. M. (2010) Carbonate microbialites and hardgrounds from Manito Lake, an alkaline, hypersaline lake in the northern Great Plains of Canada. Sed. Geol. 225, 34-49.

Lea D. W., Mashiotta T. A., and Spero H. (1999) Controls on magnesium and strontium uptake in planktonic foraminifera determined by live culturing. Geochim. Cosmochim. Acta 63, 2369-2379.

Lenders J. J. M., Dey A., Bomans P. H. H., Spielmann J., Hendrix M. M. R. M., de With G., Meldrum F. C., Harder S. and Sommerdijk N. A. J. M. (2011) High-magnesian calcite mesocrystals: A coordination chemistry approach. J. Am. Chem. Soc. 134, 1367-1373.

Léveillé R. J., Fyfe W. S. and Longstaffe F. J. (2000) Geomicrobiology of carbonate-silicate microbialites from Hawaiian basaltic sea caves. Chem. Geol. 169, 339-355.

Lippmann F. (1973) Sedimentary Carbonate Minerals. P. 228. Springer-Verlag.

Loste E., Wilson R. M., Seshadri R. and Meldrum F. C. (2003) The role of magnesium in stabilising amorphous calcium carbonate and controlling calcite morphologies. J. Cryst. Growth 254, 206-218.

Lowenstam H. A. (1981) Minerals Formed by Organisms. Science 211, 1126-1131.

Mackenzie F. T. and Pigott J. D. (1981) Tectonic controls of Phanerozoic sedimentary rock cycling. J. Geol. Soc. London 138, 183-196. 
Mackenzie F. T., Bischoff W. D., Bishop F. C., Loijens M., Schoonmaker J. and Wollast R. (1983) Magnesian calcites: Low-temperature occurrence, solubility and solid-solution behavior. Rev. Mineral. 11, 96-144.

Matthews R.K. (1968) Carbonate diagenesis: Equilibration of sedimentary mineralogy to the subaerial environment. J. Sed. Pet., 38, 1110-1119.

Morse J. W. (1983) The kinetics of calcium carbonate dissolution and precipitation. In Carbonates: Mineralogy and Chemistry. Reeder R. J. (ed.) Rev. Mineral. 11, 227-264.

Mucci A. and Morse J. W. (1983) The incorporation of $\mathrm{Mg}^{2+}$ and $\mathrm{Sr}^{2+}$ into calcite overgrowths: Influences of growth rate and solution composition. Geochim. Cosmochim. Acta 47, 217233.

Mucci A., Morse J. W., and Kaminsky M. S. (1985) Auger spectroscopy analysis of magnesian calcite overgrowths precipitated from seawater and solutions of similar composition. Amer. J. Sci. 285, 289-305.

Mucci A. (1987) Influence of temperature on the composition of magnesian calcite overgrowths precipitated from seawater. Geochim. Cosmochim. Acta 51, 1977-1984.

Mucci A. and Morse J. W. (1990) Chemistry of low-temperature abiotic calcites: Experimental studies on coprecipitation, stability, and fractionation. Rew. Aquatic Sci. 3, 217-254.

Munemoto T. and Fukushi K. (2008) Transformation kinetics of monohydrocalcite to aragonite in aqueous solutions. J. Mineral. Petrol. Sci. 103, 345-349.

Niedermayr A., Köhler S. J. and Dietzel M. (2013) Impacts of aqueous carbonate accumulation rate, magnesium and polyaspartic acid on calcium carbonate formation $\left(6-40^{\circ} \mathrm{C}\right)$. Chem. Geol. 340, 105-120.

Nielsen L. C. and DePaolo D. J. (2013) Ca isotope fractionation in a high-alkalinity lake system: Mono Lake, California. Geochim. Cosmochim. Acta 118, 276-294.

Nielsen M. H., Aloni S., and De Yoreo (2014) In situ TEM imaging of CaCO3 nucleation reveals coexistence of direct and indirect pathways. Science, 345, 1158-1162.

Nishiyama R., Munemoto T. and Fukushi K. (2013) Formation condition of monohydrocalcite from $\mathrm{CaCl}_{2}-\mathrm{MgCl}_{2}-\mathrm{Na}_{2} \mathrm{CO}_{3}$ solutions. Geochim. Cosmochim. Acta 100, 217-231.

Nudelman F., Chen H. H., Goldberg H. A., Weiner S. and Addadi L. (2007) Lessons from biomineralization: comparing the growth strategies of mollusc shell prismatic and nacreous layers in Atrina rigida. Faraday Discuss. 136, 9-25.

NürnbergD., Buma J. and Hemleben C. (1996) Assessing the reliability of magnesium in foraminiferal calcite as a proxy for water mass temperatures. Geochim. Cosmochim. Acta 60, 803-814.

Plummer L. N. and Busenberg E. (1982) The solubilities of calcite, aragonite and vaterite in $\mathrm{CO}_{2}-\mathrm{H}_{2} \mathrm{O}$ solutions between 0 and $90^{\circ} \mathrm{C}$, and an evaluation of the aqueous model for the system $\mathrm{CaCO}_{3}-\mathrm{CO}_{2}-\mathrm{H}_{2} \mathrm{O}$. Geochim. Cosmochim. Acta. 46, 1011-1040.

Politi Y., Metzler R. A., Abrecht M., Gilbert B., Wilt F. H., Sagi I., Addadi L., Weiner S. and Gilbert P. U. P. A. (2008) Transformation mechanism of amorphous calcium carbonate into calcite in the sea urchin larval spicule Proc. Natl. Acad. Sci. U. S. A. 105, 17362-17366.

Politi Y., Batchelor D. R., Zaslansky P., Chmelka B. F., Weaver J. C., Sagi I., Weiner S., and Addadi L. (2010) Role of magnesium ion in the stabilization of biogenic amorphous calcium carbonate: A structure-function investigation. Chem. Mater. 22, 161-166.

Radha A. V., Fernandez-Martinez A., Hu Y., Jun Y.-S., Waychunas G. A. and Navrotsky A. (2012) Energetic and structural studies of amorphous $\mathrm{Ca}_{1-\mathrm{x}} \mathrm{Mg}_{\mathrm{x}} \mathrm{CO}_{3} \cdot \mathrm{nH}_{2} \mathrm{O}(0 \leq \mathrm{x} \leq 1)$. Geochim. Cosmochim. Acta 90, 83-95. 
Raz S., Weiner S. and Addadi L. (2000) Formation of high-magnesium calcites via an amorphous precursor phase: Possible biological implications. Adv. Mater. 12, 38-42.

Rivadeneyra M. A., Párraga J., Delgado R., Ramos-Cormenzana A. and Delgado G. (2004) Biomineralization of carbonates by Halobacillus trueperi in solid and liquid media with different salinities. FEMS Microbio. Ecol. 48, 39-46.

Rodriguez-Blanco J. D., Shaw, S. and Benning, L. G. (2011) The kinetics and mechanisms of amorphous calcium carbonate (ACC) crystallization to calcite, via vaterite. Nanoscale $\mathbf{3}$, $265-271$.

Rodriguez-Blanco J. D., Shaw S., Bots P., Roncal-Herrero T. and Benning L. G. (2012) The role of $\mathrm{pH}$ and $\mathrm{Mg}$ on the stability and crystallization of amorphous calcium carbonate. J. Alloys \& Compounds 536, Supplement 1, S477-S479.

Rodriguez-Blanco J. D., Shaw S., Bots P., Roncal-Herrero T. and Benning L. G. (2014) The role of Mg in the crystallization of monohydrocalcite. Geochim. Cosmochim. Acta 127, 204-220.

Rosenthal Y., Boyle E. A. and Slowey N. (1997) Temperature control on the incporporation of magnesium, strontium, fluorine, and cadmium into benthic foraminiferal shells from Little Bahama Bank: Prospects for thermocline paleoceanography. Geochim. Cosmochim. Acta 61, 3633-3643.

Ross D.J. (1991) Botryoidal high-magnesium calcite marine cements from the upper Cretaceous of the Mediterranean Region. J. Sed. Res. 61, 349-353.

Russell A. D., Hönisch B., Spero H. and Lea D. W. (2004) Effects of seawater carbonate ion concentration and temperature on shell $\mathrm{U}, \mathrm{Mg}$, and $\mathrm{Sr}$ in cultured planktonic foraminifera. Geochim. Cosmochim. Acta 68, 4347-4361.

Sánchez-Román M., Vasconcelos C., Schmid T., Dittrich M. McKenzie J. A., Zenobi R. and Rivadeneyra M.A. (2008) Aerobic microbial dolomite at the nanometer scale: Implication for the geologic record. Geology 36, 879-882.

Sánchez-Román M., Romanek C. S., Fernández-Remolar D. C., Sánchez-Navas A., McKenzie J. A., Pibernat R. A., and Vasconcelos C. (2011) Aerobic biomineralization of Mg-rich carbonates: Implications for natural environments. Chem. Geol. 281, 143-150.

Sand K. K., Rodriguez-Blanco J. D., Makovicky E., Benning L. G. and Stipp S. L. S. (2011) Crystallization of $\mathrm{CaCO}_{3}$ in water-alcohol mixtures: Spherulitic growth, polymorph stabilization, and morphology change. Cryst. Growth \& Des 12, 842-853.

Sandberg P. A. (1983) An oscillating trend in Phanerozoic non-skeletal carbonate mineralogy. Nature 305, 1-22.

Schmidt M. P., Ilott A. J., Phillips B. L. and Reeder R. J. (2014) Structural changes upon dehydration of amorphous calcium carbonate. Cryst. Growth Des. 14, 938-951.

Señorale-Pose M., Chalar C., Dauphin Y., Massard P., Pradel P. and MarÌn M. (2008) Monohydrocalcite in calcareous corpuscles of Mesocestoides corti. Experiment. Parasit. 118, 54-58.

Smeets P. J. M., Cho K. R., Kempen R. G. E., Sommerdijk N. A. J. M. and De Yoreo J. J. (2015) Calcium carbonate nucleation driven by ion binding in a biomimetic matrix revealed by in situ electron microscopy. Nat. Mater. 14, 394-399.

Solotchina E. P., Prokopenko A. A., Kuzmin M. I., Solotchin P. A. and Zhdanova A. N. (2009) Climate signals in sediment mineralogy of Lake Baikal and Lake Hovsgol during the LGMHolocene transition and the 1-Ma carbonate record from the HDP-04 drill core. Quat.

Internat. 205, 38-52. 
Stephenson A. E., De Yoreo J. J., Wu L., Hoyer J. and Dove P. M. (2008) Peptides enhance magnesium signature in calcite: Insights into origins of vital effects. Science 322, 724-727.

Stephenson A. E., Hunter J. L., Han N., De Yoreo J. J., and Dove P. M. (2011) Effect of ionic strength on the $\mathrm{Mg}$ content of calcite: Toward a physical basis for minor element uptake during step growth. Geochim Cosmochim. Acta. 75, 4340-4350.

Stoffers P. and Fischbeck R. (1974) Monohydrocalcite in the sediments of Lake Kivu (East Africa). Sedimentology 21, 163-170.

Swainson I. P. (2008) The structure of monohydrocalcite and the phase composition of the beachrock deposits of Lake Butler and Lake Fellmongery, South Australia. Am. Mineral. 93, 1014-1018.

Tao J., Zhou D., Zhang Z., Xu X. and Tang R. (2009) Magnesium-aspartate-based crystallization switch inspired from shell molt of crustacean. Proc. Natl. Acad. Sci. U. S. A. 106, 2209622101.

Thompson J. B. and Ferris F. G. (1990) Cyanobacterial precipitation of gypsum, calcite, and magnesite from natural alkaline lake water. Geology 18, 995-998.

Taylor G. F. (1975) The occurrence of monohydrocalcite in two small lakes in the South-East of South Australia. Am. Mineral. 60, 690-697.

Vegard L. (1921) Die Konstitution der Mischkristalle und die Raumfüllung der Atome. Zeitschrift für Physik 5, 17.

Wang D., Wallace A. F., De Yoreo J. J. and Dove P. M. (2009) Carboxylated molecules regulate magnesium content of amorphous calcium carbonates during calcification. Proc. Natl. Acad. Sci. U. S. A. 106, 21511-21516.

Wang D., Hamm L. M., Giuffre A. J., Echigo T., Rimstidt J. D., De Yoreo J. J., Grotzinger J. and Dove P. M. (2012) Revisiting geochemical controls on patterns of carbonate deposition through the lens of multiple pathways to mineralization. Faraday Discuss. 159, 1-16.

Weiss I. M., Tuross N., Addadi L. and Weiner S. (2002) Mollusc larval shell formation: amorphous calcium carbonate is a precursor phase for aragonite. J. Experiment. Zoo. 293, 478-491.

Wilkinson B. H. and Given R. K. (1986) Secular variation in abiotic marine carbonates: Constraints on Phanerozoic atmospheric carbon dioxide contents and oceanic $\mathrm{Mg} / \mathrm{Ca}$ ratios. J. Geol. 94, 321-333.

Zhang Z., Xie Y., Xu X., Pan H. and Tang R. (2012) Transformation of amorphous calcium carbonate into aragonite. J. Cryst. Growth 343, 62-67.

Zhong S. and Mucci A. (1989) Calcite and aragonite precipitation from seawater solutions of various salinities: Precipitation rates and overgrowth compositions. Chem. Geol. 78, 283299. 


\section{Captions only.}

Fig. 1. Schematic of the mixed flow reactor system used in this study (after Blue et al., 2013). Arrows indicate the direction of flow. Star denotes the location of the filter.

Fig. 2. SEM images show the morphologies and sizes of the synthesized products. A representative SEM image of each polymorph observed in this study is shown. (A) ACC; (B) Low-Mg calcite with 6\% Mg; (C) High-Mg calcite with 20\% Mg; (D) Aragonite; (E) Monohydrocalcite; (F) Vaterite.

Fig. 3. Typical X-ray Diffraction patterns collected for each polymorph that formed in this study. (A) ACC; (B) low-Mg calcite with a pure calcite standard (Iceland Spar, Ward's Science) shown for reference; (C) high-Mg calcite with a pure calcite standard (Iceland Spar, Ward's Science) shown for reference; (D) aragonite with a standard (Ward's Science) shown for reference; (E) monohydrocalcite; (F) vaterite.

Fig. 4. The solution composition associated with ACC formation produces fields of crystalline polymorphs when quantified as $a \mathrm{Mg}^{2+} / a \mathrm{Ca}^{2+}$ and the $a \mathrm{CO}_{3}{ }^{2-} / a \mathrm{Ca}^{2+}$. (A) When the ACC-solution slurry is stirred during the transformation, monohydrocalcite (MHC) is formed for a broad range of conditions. MHC eventually transforms to aragonite (for all conditions), nesquehonite, and possibly hydromagnesite (at the highest $\mathrm{Mg}$ levels). (B) The time required for ACC to transform into the initial crystalline polymorph correlates with solution $\mathrm{Mg} / \mathrm{Ca}$. Calcite forms in low to moderate $\mathrm{Mg} / \mathrm{Ca}\left(\mathrm{O}_{-}\right.$ 4) and transforms between within three hours. Aragonite occurs when $\mathrm{Mg} / \mathrm{Ca}$ is moderately high $(\sim 5)$ and transformation requires up to 10 hours. MHC is formed when solutions begin with higher $\mathrm{Mg} / \mathrm{Ca}(>4)$ and the transformation is generally slow, sometimes up to 45 hours.

Fig. 5. The time required for ACC to transform to calcite increases with the steady state solution $\mathrm{Mg}: \mathrm{Ca}$ ratio for $\mathbf{A})$ stirred and $\mathbf{B}$ ) unstirred conditions. For a given ratio of $\mathrm{Mg}: \mathrm{Ca}$ in solution, the resulting calcites produce similar compositions and transformation times. However, in the absence of stirring, the $\mathrm{Mg}$ content of calcites that can transform is almost doubled to $26 \mathrm{~mole} \%$. At higher $\mathrm{Mg} / \mathrm{Ca}$ levels, for stirred and unstirred conditions, the transformation produces $\mathrm{MHC}$. 
Fig. 6. The transformation of ACC shows a polymorph-specific evolution of solution chemistry for stirred conditions. The representative experiment numbers are reported in Table A1 (Appendix). Black dots (Time $=0$ hours) show initial conditions upon ACC formation, diamonds indicate solution measurements at specific time points, and open diamonds show the time point for ACC transformation to calcite (blue) or low $\mathrm{Mg}$ monohydrocalcite (green). These calcite experiments ended with minor amounts of aragonite. The curves provide a visual guide to the progress of individual experiments and are not a quantitative fit to the data. When ACC transforms to calcite, (A) $\mathrm{pH}$ decreases sharply and the $\mathrm{Mg} / \mathrm{Ca}$ of solutions show small, monotonic increases. In contrast, as ACC transforms to monohydrocalcite, (C) $\mathrm{pH}$ maintains near-constant values and (D) $\mathrm{Mg} / \mathrm{Ca}$ increases sharply at the time of $\mathrm{MHC}$ formation, with a continued rise to ratios exceeding 100 .

Fig. 7. The Mg content of calcite that forms from ACC has a 1:1 dependence on the composition of the initial ACC. This relationship is independent of whether the transformation occurs while stirring for the range of conditions that calcite is formed. Recall that the maximum $\mathrm{Mg}$ content of calcites from the stirred experiments is limited by the formation of MHC (see Fig. 4). Data provided in Table A2 (Appendix).

Fig. 8. A compilation of data from multiple studies shows calcite composition is correlated with the $\mathrm{Mg} / \mathrm{Ca}$ of the solution from which the mineral grew. In the relatively simple solutions of this study, the data indicate $a \approx 3: 1$ dependence whether the calcite formed directly from solution by a step growth process (data from Davis et al., 2000 and Stephenson et al., 2008) or by the transformation from ACC (this study). In synthetic seawater, measurements compiled from three studies of seeded growth (Mucci and Morse, 1990) show a correlation offset to $a \approx 1: 1$ dependence (see Section 4.3 and data in Appendix Table A3). 
Table 1. Experimental studies of ACC transformation into crystalline polymorphs with calcite compositions.

\begin{tabular}{|c|c|c|c|c|c|c|}
\hline Study & Synthesis method & $\begin{array}{l}\text { Temp } \\
\left({ }^{\circ} \mathrm{C}\right)\end{array}$ & $\begin{array}{l}\text { Initial } \\
{[\mathrm{Mg}]:[\mathrm{Ca}]}\end{array}$ & $\begin{array}{l}\text { Initial } \\
{\left[\mathrm{CO}_{3}{ }^{2-}\right](\mathrm{M})}\end{array}$ & Phases reported $^{1}$ & $\begin{array}{l}\text { Calcite } \\
\text { mol\% Mg }\end{array}$ \\
\hline \multicolumn{7}{|c|}{ Stirring during ACC transformation } \\
\hline Sand et al., 2011 & $\begin{array}{l}\text { Batch reactor with } \\
\mathrm{Na}_{2} \mathrm{CO}_{3}{ }^{2}\end{array}$ & 24 & $\mathrm{n} / \mathrm{a}$ & 0.025 & ACC; Calc.; Arag.; Vat. & $\mathrm{n} / \mathrm{a}$ \\
\hline Nishiyama et al., 2012 & $\begin{array}{l}\text { Batch reactor with } \\
\mathrm{Na}_{2} \mathrm{CO}_{3}\end{array}$ & 25 & $0-2: 1$ & $0.03-1.0$ & ACC; MHC; Calc.; Vat. & $0-8$ \\
\hline $\begin{array}{l}\text { Rodriguez-Blanco et al., } \\
2012\end{array}$ & $\begin{array}{l}\text { Batch reactor with } \\
\mathrm{Na}_{2} \mathrm{CO}_{3}\end{array}$ & $10-25$ & $0 ; 9: 1$ & 1.0 & ACC; Calc.; Vat. & 10 \\
\hline Zhang et al., 2012 & $\begin{array}{l}\text { Batch reactor with } \\
\text { Dimethyl carbonate }^{3}\end{array}$ & 30 & $0-5: 1$ & 0.06 & ACC; MHC; Calc.; Arag. & not reported \\
\hline Niedermayr et al., 2013 & $\mathrm{CO}_{2}$ diffusion & $6-40$ & $0-5: 1$ & variable & ACC; Vat.; Arag.; Calc. & $0-4$ \\
\hline $\begin{array}{l}\text { Rodriguez-Blanco et al., } \\
2014\end{array}$ & $\begin{array}{l}\text { Batch reactor with } \\
\mathrm{Na}_{2} \mathrm{CO}_{3}\end{array}$ & 21 & $7: 3$ & 1.0 & ACC; $\mathrm{MHC}^{4}$; Calc. & $3-7$ \\
\hline This study & $\begin{array}{l}\text { Mixed flow reactor } \\
\text { with } \mathrm{NaHCO}_{3}\end{array}$ & 25 & $0.4: 1-6: 1$ & $0.05-0.20$ & $\begin{array}{l}\text { ACC; Vat.; Calc.; Arag.; } \\
\text { MHC }\end{array}$ & $4-13$ \\
\hline \multicolumn{7}{|c|}{ No stirring during ACC transformation } \\
\hline Towe and Malone, 1970 & $\left(\mathrm{NH}_{4}\right)_{2} \mathrm{CO}_{3}$ diffusion & $23-25$ & $5: 1$ & not reported & $\begin{array}{l}\text { ACC; MHC; Nesq.; } \\
\text { Arag.; H-Mg calc. }\end{array}$ & $3-32$ \\
\hline Raz et al., 2000 & $\left(\mathrm{NH}_{4}\right)_{2} \mathrm{CO}_{3}$ diffusion & 25 & $4: 1$ & not reported & ACC; Arag.; H-Mg calc. & $11-14$ \\
\hline Loste et al., 2003 & $\begin{array}{l}\text { Batch reactor with } \\
\mathrm{NaHCO}_{3} \text { (open to air) }\end{array}$ & 25 & $0-10: 1$ & 0.54 & $\begin{array}{l}\text { ACC; MHC; Arag.; Vat.; } \\
\text { H-Mg calc. }\end{array}$ & $\begin{array}{l}0-22 \text { (top \& } \\
\text { bottom samples) }\end{array}$ \\
\hline Ajikumar et al., 2005 & $\left(\mathrm{NH}_{4}\right)_{2} \mathrm{CO}_{3}$ diffusion & $4 ; 25$ & $1: 9-1: 3$ & not reported & ACC; Calc. & "low Mg" \\
\hline Lam et al., 2007 & $\left(\mathrm{NH}_{4}\right)_{2} \mathrm{CO}_{3}$ diffusion & 25 & $2: 1-9: 1$ & not reported & ACC; Nesq.; MHC & $\mathrm{n} / \mathrm{a}$ \\
\hline Wang et al., 2012 & $\left(\mathrm{NH}_{4}\right)_{2} \mathrm{CO}_{3}$ diffusion & 25 & $0-6: 1$ & 5.2 & ACC; H-Mg calc.; Arag & $0-40$ \\
\hline Han et al., 2013 & $\begin{array}{l}\text { Batch reactor with } \\
\mathrm{NaHCO}_{3}\end{array}$ & 25 & $0.5: 1-10: 1$ & 0.20 & ACC; H-Mg calc. & $10-30$ \\
\hline This study & $\begin{array}{l}\text { Mixed flow reactor } \\
\text { with } \mathrm{NaHCO}_{3}\end{array}$ & 25 & $0.4: 1-6.5: 1$ & $0.07-0.20$ & ACC; $M H C ; \boldsymbol{H}-\mathbf{M g}$ calc. & $7-28$ \\
\hline
\end{tabular}

${ }^{1} \mathrm{ACC}=$ amorphous calcium carbonate; Calc $=$ Calcite; Arag. = Aragonite; Vat. = Vaterite; $\mathrm{MHC}=$ Monohydrocalcite; H-Mg = High-Mg; Nesq. $=$ Nesquehonite $\left(\mathrm{MgCO}_{3} \bullet 3 \mathrm{H}_{2} \mathrm{O}\right) .{ }^{2}$ Stirring was gentle versus vigorous. ${ }^{3}$ Stirring by shaking.

${ }^{4}$ Produced high Mg MHC that subsequently transformed to low Mg MHC. 
Chemical and physical controls on the transformation of amorphous calcium carbonate into crystalline $\mathrm{CaCO}_{3}$ polymorphs

C.R. Blue, A. Giuffre, S. Mergelsberg, N. Han, J.J. De Yoreo and P.M. Dove

\section{FIGURES WITH CAPTIONS}

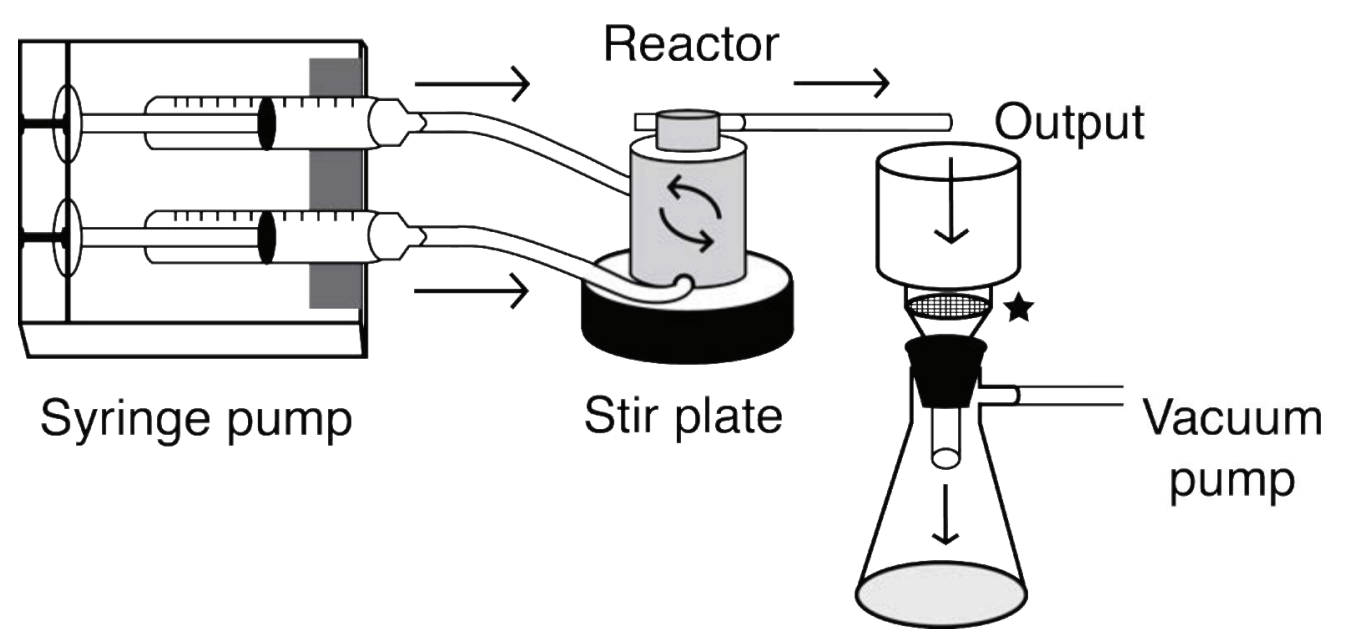

Fig. 1. Schematic of the mixed flow reactor system used in this study (after Blue et al., 2013). Arrows indicate the direction of flow. Star denotes the location of the filter. 


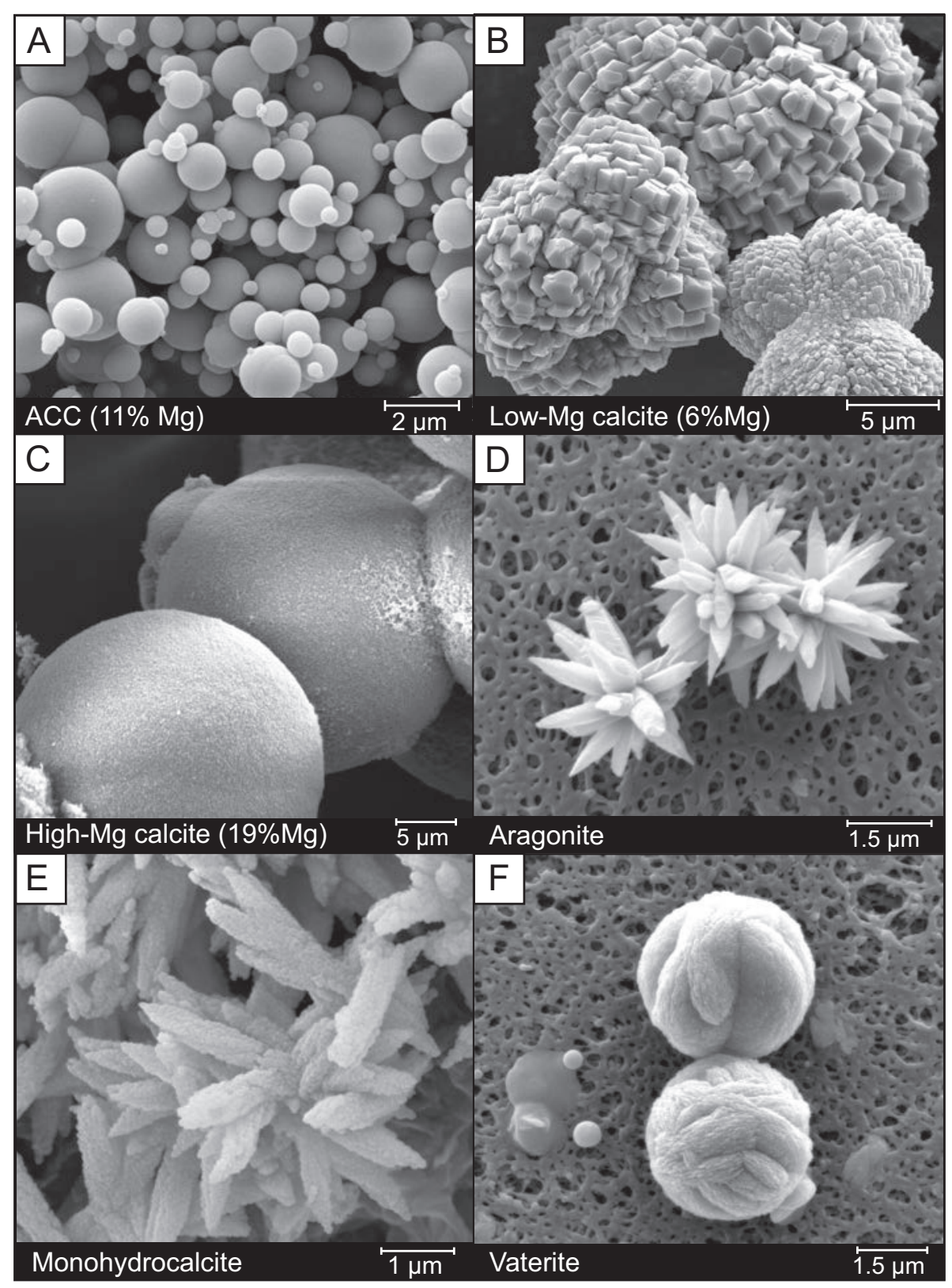

Fig. 2. SEM images show the morphologies and sizes of the synthesized products. A representative SEM image of each polymorph observed in this study is shown. (A) ACC; (B) Low-Mg calcite with 6\% Mg; (C) High-Mg calcite with 20\% Mg; (D) Aragonite; (E) Monohydrocalcite; (F) Vaterite. 


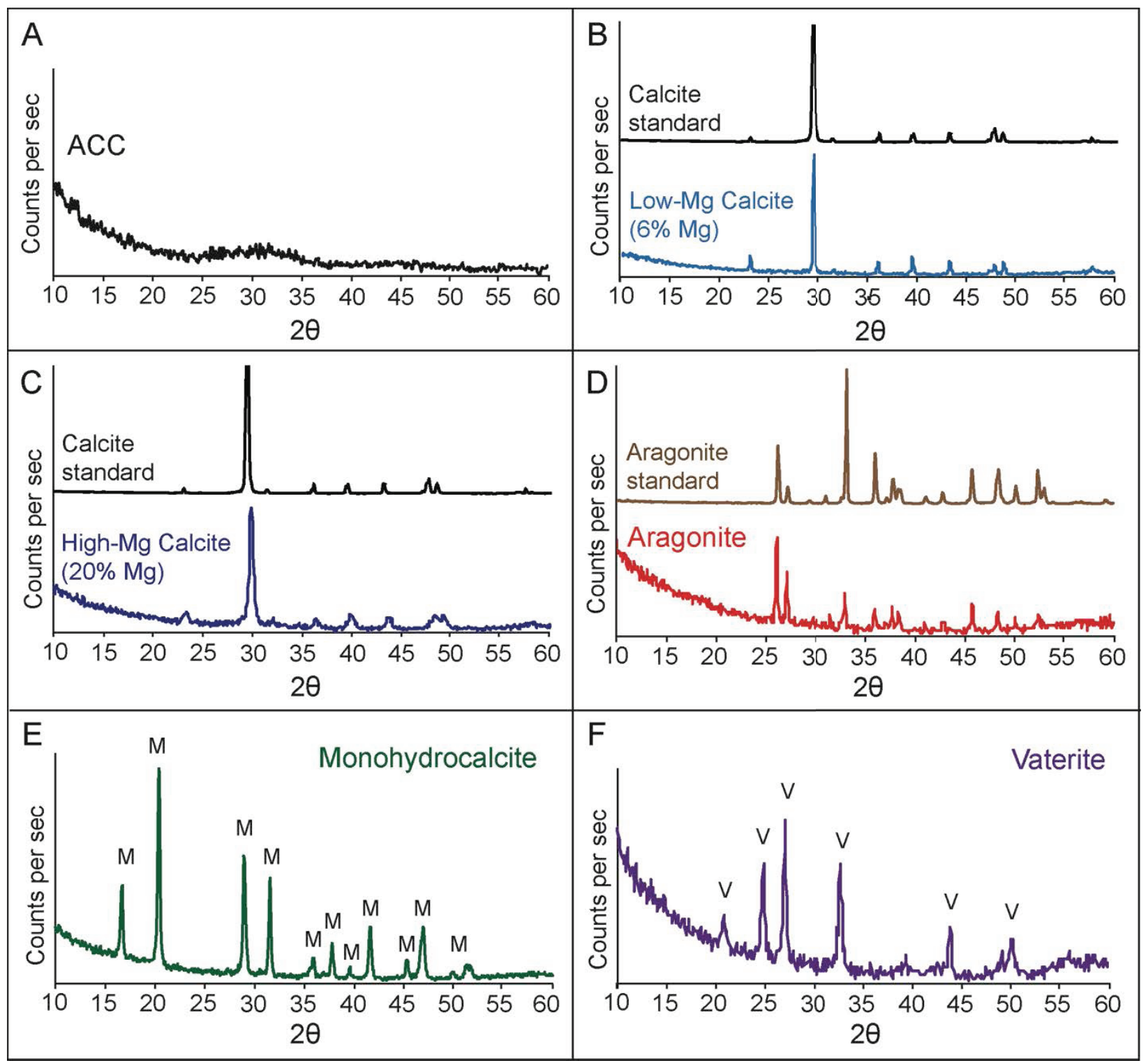

Fig. 3. Typical X-ray Diffraction patterns collected for each polymorph that formed in this study. (A) ACC; (B) low-Mg calcite with a pure calcite standard (Iceland Spar, Ward's Science) shown for reference; (C) high-Mg calcite with a pure calcite standard (Iceland Spar, Ward's Science) shown for reference; (D) aragonite with a standard (Ward's Science) shown for reference; (E) monohydrocalcite; (F) vaterite. 

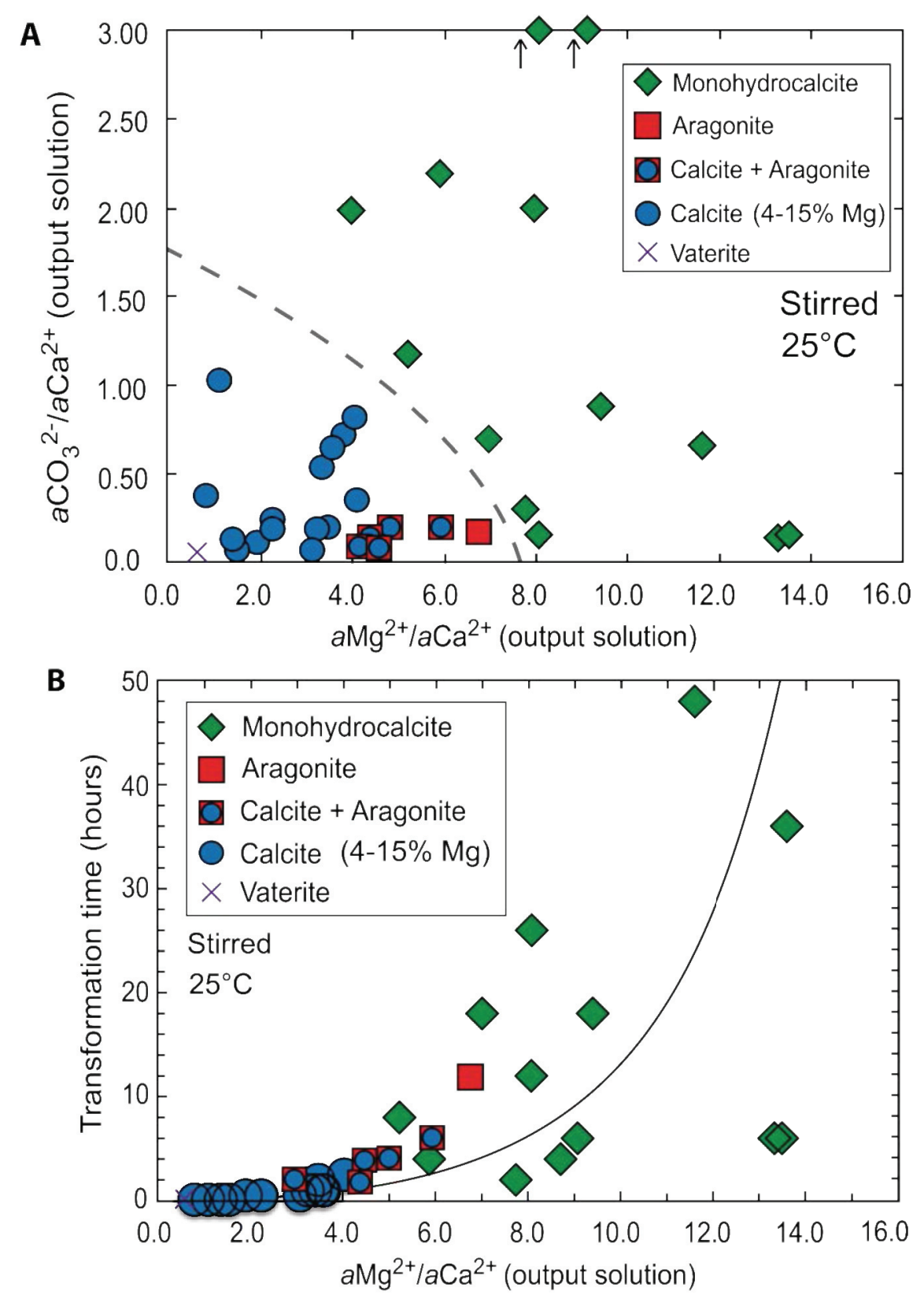

Fig. 4. The solution composition associated with $\mathrm{ACC}$ formation produces fields of crystalline polymorphs when quantified as $a \mathrm{Mg}^{2+} / a \mathrm{Ca}^{2+}$ and the $a \mathrm{CO}_{3}{ }^{2-} / a \mathrm{Ca}^{2+}$. (A) When the ACC-solution slurry is stirred during the transformation, monohydrocalcite (MHC) is formed for a broad range of conditions. MHC eventually transforms to aragonite (for all conditions), nesquehonite, and possibly hydromagnesite (at the highest $\mathrm{Mg}$ levels). (B) The time required for ACC to transform into the initial crystalline polymorph correlates with solution $\mathrm{Mg} / \mathrm{Ca}$. Calcite forms in low to moderate $\mathrm{Mg} / \mathrm{Ca}(0$ 4) and transforms between within three hours. Aragonite occurs when $\mathrm{Mg} / \mathrm{Ca}$ is moderately high $(\sim 5)$ and transformation requires up to 10 hours. MHC is formed when solutions begin with higher $\mathrm{Mg} / \mathrm{Ca}(>4)$ and the transformation is generally slow, sometimes up to 45 hours. 

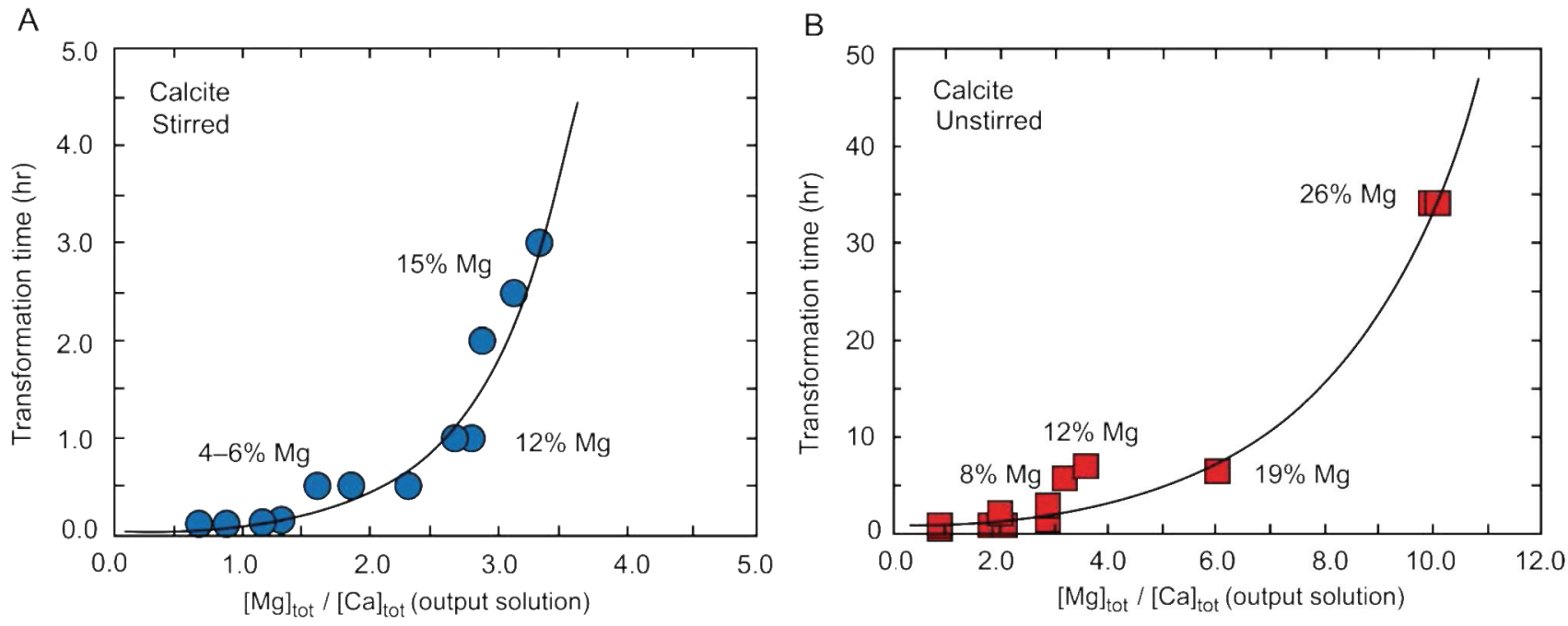

Fig. 5. The time required for $\mathrm{ACC}$ to transform to calcite increases with the steady state solution $\mathrm{Mg}: \mathrm{Ca}$ ratio for $\mathbf{A}$ ) stirred and $\mathbf{B}$ ) unstirred conditions. For a given ratio of $\mathrm{Mg}: \mathrm{Ca}$ in solution, the resulting calcites produce similar compositions and transformation times. However, in the absence of stirring, the $\mathrm{Mg}$ content of calcites that can transform is almost doubled to $26 \mathrm{~mole} \%$. At higher $\mathrm{Mg} / \mathrm{Ca}$ levels, for stirred and unstirred conditions, the transformation produces MHC. 
A
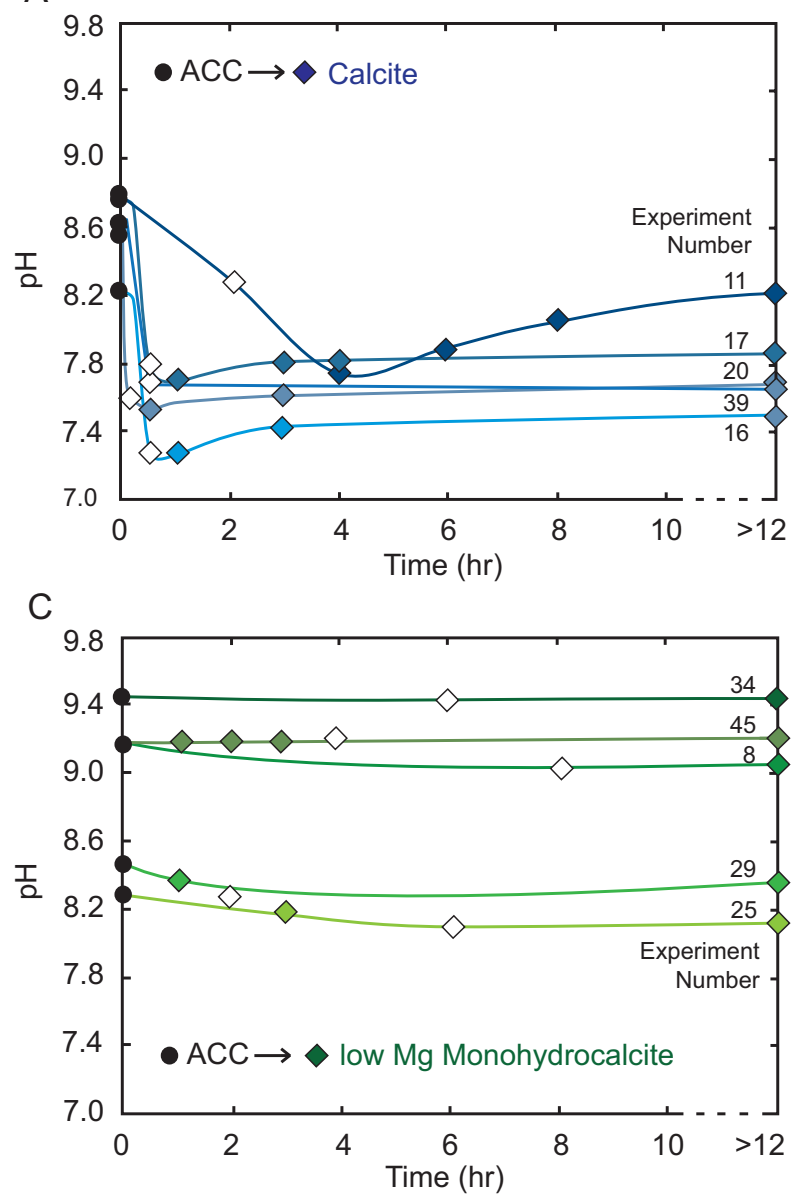

B
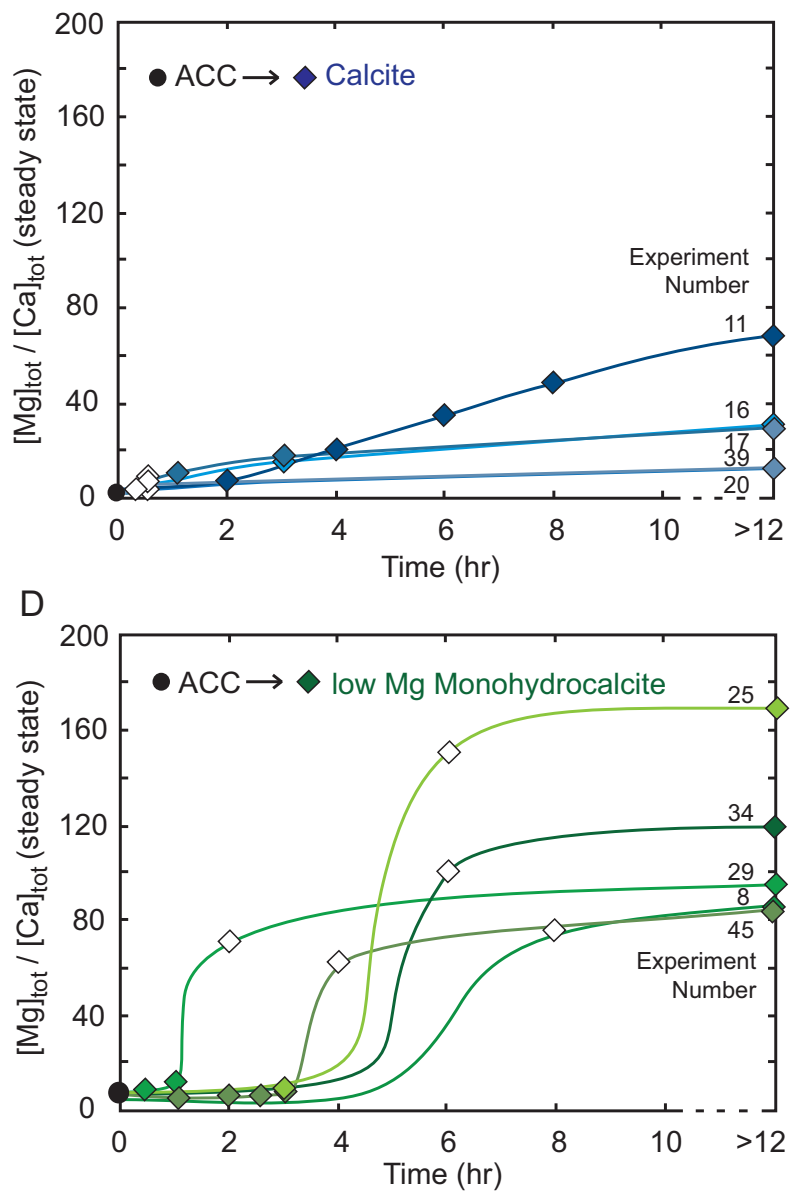

Fig. 6. The transformation of ACC shows a polymorph-specific evolution of solution chemistry for stirred conditions. The representative experiment numbers are reported in Table A1 (Appendix). Black dots (Time $=0$ hours) show initial conditions upon ACC formation, diamonds indicate solution measurements at specific time points, and open diamonds show the time point for ACC transformation to calcite (blue) or low $\mathrm{Mg}$ monohydrocalcite (green). These calcite experiments ended with minor amounts of aragonite. The curves provide a visual guide to the progress of individual experiments and are not a quantitative fit to the data. When ACC transforms to calcite, (A) $\mathrm{pH}$ decreases sharply and the $\mathrm{Mg} / \mathrm{Ca}$ of solutions show small, monotonic increases. In contrast, as ACC transforms to monohydrocalcite, (C) $\mathrm{pH}$ maintains near-constant values and (D) $\mathrm{Mg} / \mathrm{Ca}$ increases sharply at the time of $\mathrm{MHC}$ formation, with a continued rise to ratios exceeding 100 . 


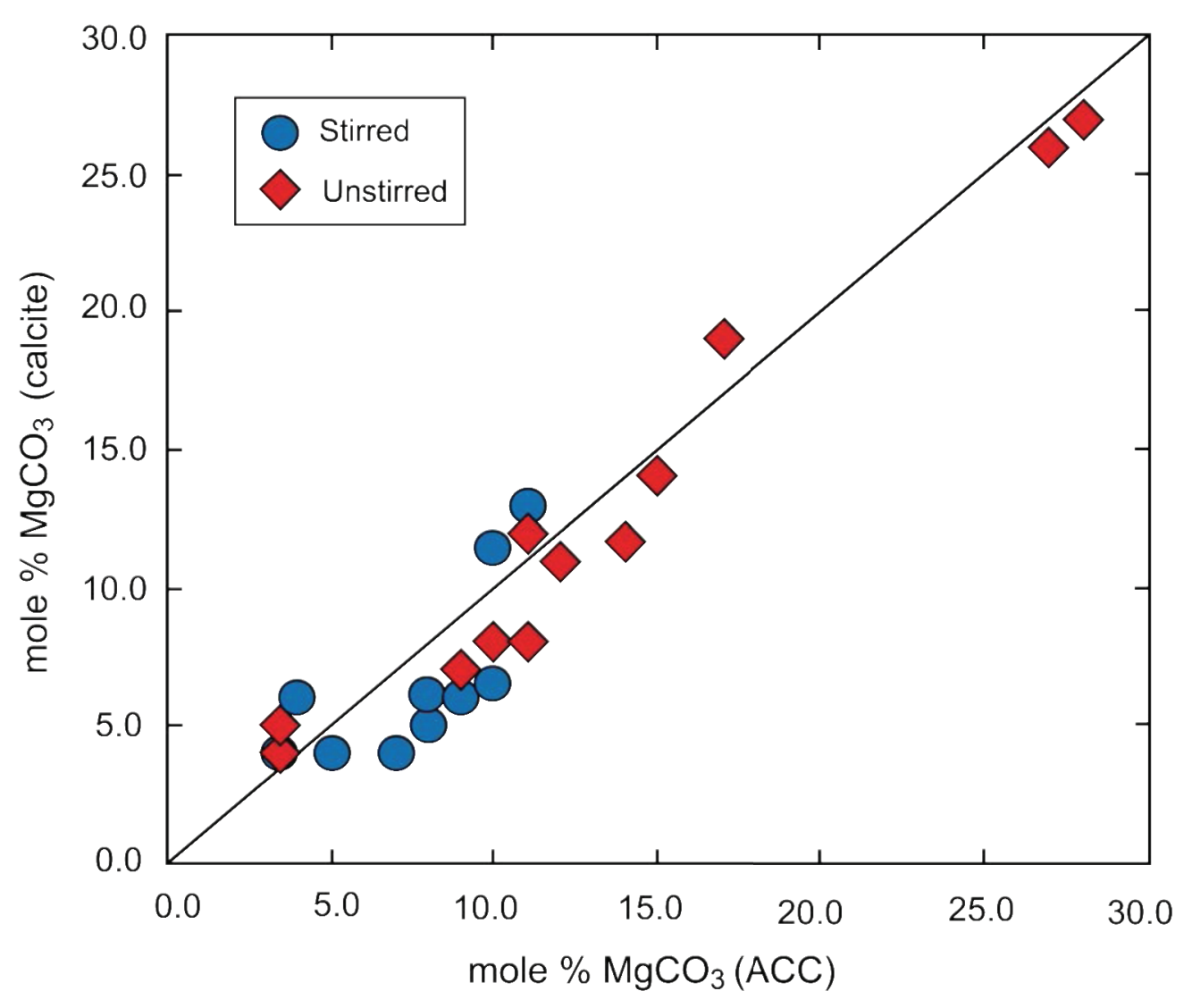

Fig. 7. The Mg content of calcite that forms from ACC has a 1:1 dependence on the composition of the initial ACC. This relationship is independent of whether the transformation occurs while stirring for the range of conditions that calcite is formed. Recall that the maximum $\mathrm{Mg}$ content of calcites from the stirred experiments is limited by the formation of MHC (see Fig. 4). Data provided in Table A2 (Appendix). 


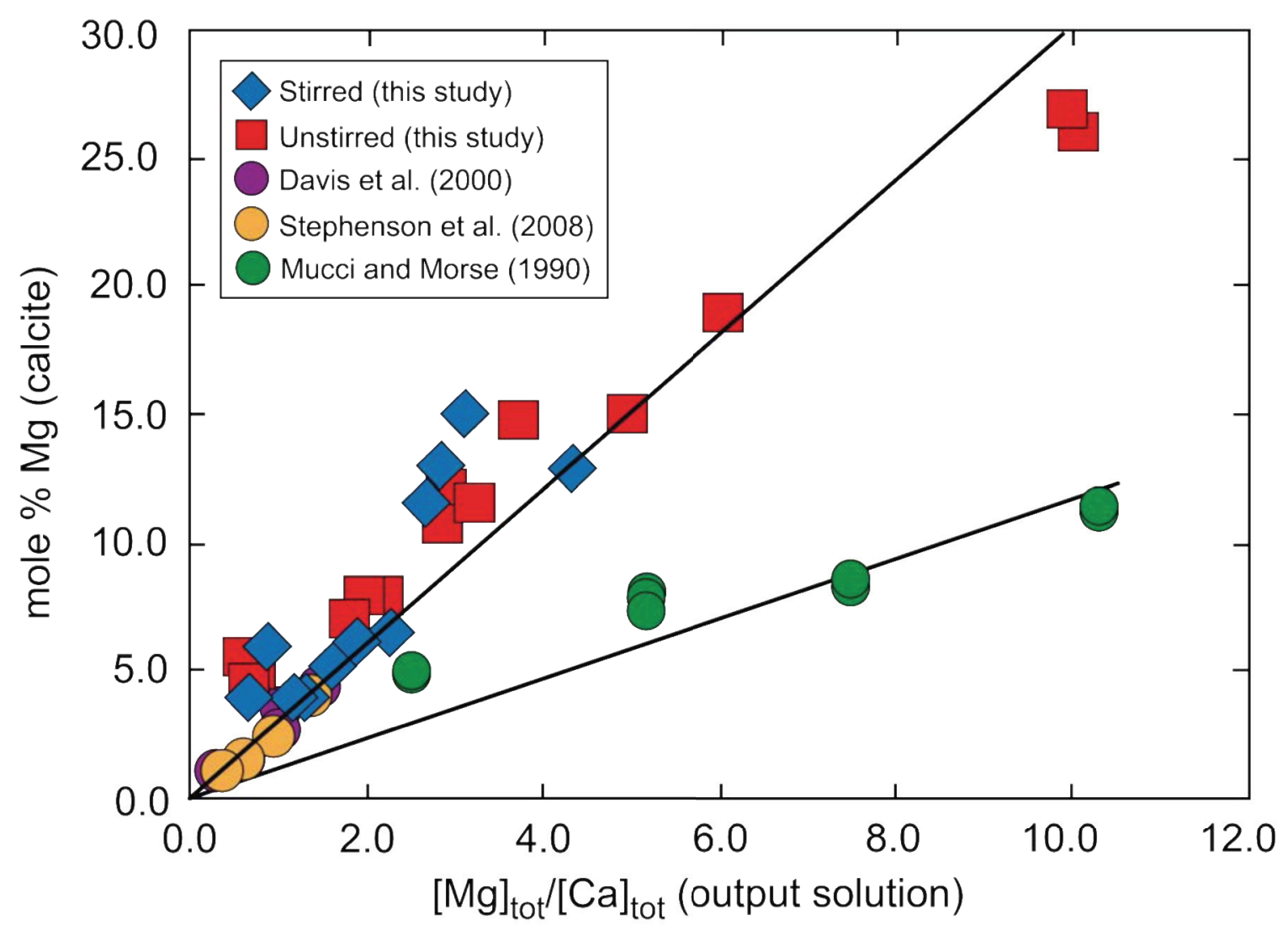

Fig. 8. A compilation of data from multiple studies shows calcite composition is correlated with the $\mathrm{Mg} / \mathrm{Ca}$ of the solution from which the mineral grew. In the relatively simple solutions of this study, the data indicate $a \approx 3: 1$ dependence whether the calcite formed directly from solution by a step growth process (data from Davis et al., 2000 and Stephenson et al., 2008) or by the transformation from ACC (this study). In synthetic seawater, measurements compiled from three studies of seeded growth (Mucci and Morse, 1990) show a correlation offset to a $\approx 1: 1$ dependence (see Section 4.3 and data in Appendix Table A3). 